Article

\title{
An Experimental Study for the Remediation of Industrial Waste Water Using a Combination of Low Cost Mineral Raw Materials
}

\author{
Petros Petrounias ${ }^{1, *(\mathbb{D}}$, Aikaterini Rogkala ${ }^{1}$, Panagiota P. Giannakopoulou ${ }^{1}$, \\ Basilios Tsikouras ${ }^{2}{ }^{(D}$, Paraskevi Lampropoulou ${ }^{1}$, Stavros Kalaitzidis ${ }^{1}(\mathbb{D}$, \\ Konstantin Hatzipanagiotou ${ }^{1}$, Nicolaos Lambrakis ${ }^{3}$ and Marina A. Christopoulou ${ }^{1}$ \\ 1 Section of Earth Materials, Department of Geology, University of Patras, 26504 Patras, Greece; \\ krogkala@upatras.gr (A.R.); peny_giannakopoulou@windowslive.com (P.P.G.); \\ p.lampropoulou@upatras.gr (P.L.); skalait@upatras.gr (S.K.); k.hatzipanagiotou@upatras.gr (K.H.) \\ mchmarina@hotmail.gr (M.A.C.) \\ 2 Physical and Geological Sciences, Faculty of Science, Universiti Brunei Darussalam, Jalan Tungku Link, \\ Gadong BE1410, Bandar Seri Begawan, Brunei Darussalam; basilios.tsikouras@ubd.edu.bn \\ 3 Laboratory of Hydrogeology, Department of Geology, University of Patras, 26504 Patras, Greece; \\ nlambrakis@upatras.gr \\ * Correspondence: Geo.plan@outlook.com; Tel.: +30-2610996288
}

Received: 2 March 2019; Accepted: 27 March 2019; Published: 30 March 2019

\begin{abstract}
This paper investigates an alternative use of sterile aggregate materials which may arise from various construction applications in conjunction with other low-cost mineral raw materials to remediate the acid mine drainage phenomenon. This study is based on the combination of unprocessed mineral raw materials, as well as on the basic concept of the cyclic economy where the conversion of a waste into a raw material for another application can be achieved. In this study, in order to examine the remediation, in lab scale, of the drainage waste water of Agios Philippos mine, an experimental electrically continuous flow-driven forced device was constructed, enriching the research gap relative to this type of remediation approach. Through this experimental device, the use of certain mixes of mineral raw materials (serpentinite, andesite, magnesite, peat, and biochar) was studied. Our results focus on the impact of the studied mineral raw materials and especially on their synergy on the water purification potential under continuous water flow operation. Using the new 7-day experimental electrically continuous flow-driven forced device with certain mixes of mineral raw materials, the increase of $\mathrm{pH}$ values from 3.00 to 6.82 was achieved. Moreover, with use of the experimental device, the removal of toxic load was achieved, and more specifically the concentration of Fe was decreased from 6149 to $1300 \mathrm{ppb}, \mathrm{Cu}$ from 8847 to $35 \mathrm{ppb}$, and $\mathrm{Zn}$ from 285,458 to $50,000 \mathrm{ppb}$.
\end{abstract}

Keywords: sterile aggregates; remediation of waste water; peat; biochar

\section{Introduction}

Environmental pollution caused by toxic heavy metals constitutes a significant problem in our modern society and particularly water pollution due to the disposal of heavy metals is a great concern worldwide. Consequently, the treatment of polluted industrial waste water remains a topic of global concern since waste water discharged from municipalities, communities, and industries must ultimately be returned to receiving waters the land [1]. Acid mine lakes have been formed worldwide and are responsible for numerous water quality problems, which severely limit their beneficial uses and may constitute an environmental risk both in the water body itself and downstream environments 
and water resources [2-5]. Pit lakes or mining lakes, which are unique water bodies, such as the one at Agios Philippos (south of Alexandroupoli, Evros Prefecture, Greece) form in many places of the world as a consequence of opencast mining. When the activity ceases, the open pit is back filled with groundwater and surface water. The rate of filling is dependent on climatic and geologic conditions, as well as the regional hydrologic characteristics. Assessment of the environmental risks of pit lake development is imperative for the mining industry and the public, especially in cases of high sulphidation deposits characterized by high concentrations of heavy metals [6]. Pit lakes forming from such deposits pose a significant threat to the environment since they are often acidic, containing elevated concentrations of metals (e.g., $\mathrm{Fe}, \mathrm{Al}, \mathrm{Pb}, \mathrm{Cu}, \mathrm{Zn}, \mathrm{Mn}, \mathrm{Cd}$ ) and metalloids (e.g., $\mathrm{As}, \mathrm{Sb}$ ), and show high acid generation potential because they have very low buffering capacity [7-9]. In many cases, sulfide minerals in the dumps are oxidized upon contact with air, producing metal oxides and sulfuric acid. After mine closure, the open pits are filled with re-ascending groundwater or rainwater, which flush the acid solutions and the metals from the dumps into the lake water. This results in severe acidification of these lakes ( $\mathrm{pH} 2-3$ ) and high sulfate and heavy metal concentrations. Heavy metal pollution occurs in much industrial waste water such as that produced by metal plating facilities, mining operations, battery manufacturing processes, production of paints and pigments, as well as ceramic and glass industries. This waste water commonly includes $\mathrm{Cd}, \mathrm{Pb}, \mathrm{Cu}, \mathrm{Zn}, \mathrm{Ni}$, and $\mathrm{Cr}$ [10]. Whenever heavy metals are exposed to the natural eco-system, accumulation of metal ions in human bodies will occur through either direct intake or food chains, and therefore toxic concentration of heavy metals should be prevented from reaching the natural environment [11]. In order to remove toxic heavy metals from water systems, conventional methods have been used such as chemical precipitation, coagulation, ion exchange, solvent extraction, and filtration, evaporation and membrane methods [12]. Adsorption of heavy metals on conventional adsorbents such as activated carbon have been widely used as an effective adsorbent in many applications, as well as the activated carbon produced by carbonizing organic materials constitutes the most widely used adsorbent. Various mineral raw materials have been used as chemical reagents for the neutralization of $\mathrm{pH}$, as well as for the removal of heavy metals. Several researchers have used experimental columns of batch type to examine the effect of various mineral raw materials. However, a research gap has been observed concerning the remediation of this phenomenon by using electrical driven flow forced devices. The recently proposed approaches for the remediation of this phenomenon include high cost techniques [13].

Numerous methods are available for the removal of heavy metals from aqueous solutions including chemical precipitation, ion exchange, ultra-filtration, reverse osmosis, and adsorption [14-17]. A number of researchers such as Teir et al. [18] have reported the use of various lithotypes of rocks such as magnesites, limestones, dolomites, and dunites both for increasing the $\mathrm{pH}$ values of industrial waste waters and for removing heavy metals from them. The majority of these rocks in conjunction with other lithotypes are widely used as aggregate materials in numerous industrial and construction applications by simultaneously producing a great number of steriles [19]. This fact led us to find ways to dispose these aggregate steriles. The use of serpentinite in aqueous solutions carries the risk of leaching elements, such as $\mathrm{Cr}$ and $\mathrm{Ni}$, in the system. The majority of the existing experimental researches use vertical columns that do not simulate the exact conditions of a future water treatment device and not continuous operation devices. Serpentinite comprises abundant and extensive outcrops in several ophiolite complexes in Greece and worldwide, and so therefore its use to remediate analogous quagmires is cost effective. For example, in the Veria-Naousa, ophiolite occurs near the studied Agios Philippos polluted pit lake [20-24]. Furthermore, magnesite has been widely used from several researchers for the remediation of industrial waste waters.

The use of carbon-containing materials for the adsorption of inorganic pollutants presented in water is a widespread technique, as their origin (biomass) is abundant and usually requires very little preprocessing before it is applied. There are many published papers concerning the ability of peat to bind dissolved metals, organic load, etc. Coupal and Lalancette [25] and McLellan and Rock [26] reported that peat is effective in removing heavy metals $(\mathrm{Hg})$ from a water solution by performing both 
column and batch experiments. Accumulation of sphagnum moss plant residues in peat is particularly effective in adsorbing and removing $\mathrm{Cd}$ from hypochlorite-oxidized cadmium cyanide-containing plating waste, hexavalent chromium from aqueous solutions, as well as $\mathrm{Cu}, \mathrm{Pb}, \mathrm{Cd}, \mathrm{Ni}$, and $\mathrm{Zn}$ from waste waters [27-30]. Biochar can be derived from many sources such as crop residues, stover, straw, shell, bark, wood, sludge, litter, rubber, and peat [31-35]. Peat moss-derived biochars produced from pyrolysis in different carbonization conditions have recently attracted the research interest in heavy metal adsorption [36]. However, the accurate mechanism of the adsorption of heavy metals into peat and biochar has been studied by many researchers without having been able to produce a single acceptable model of their neutralization.

The aim of this work is both the remediation of the $\mathrm{pH}$ values and the removal of toxic load ( $\mathrm{Fe}, \mathrm{Cu}, \mathrm{Zn}$ ) from acidic aqueous solutions such as pit lakes from Agios Philippos mine by using a combination of economically and environmentally friendly mineral raw materials such as sterile aggregates (serpentinite, andesite), industrial rocks (magnesite), and other natural and organic materials (peat and biochar) in a new experimental electric device when simultaneously filling the research gaps relative to those objects.

\section{Geologic Description}

In this study, the area of Agios Philippos Kirkis mines (southern of Alexandroupoli, Evros Prefecture, Greece) was selected for water and sediment sampling (Figure 1a). This area is well-known for the acidic runoff, which is promoted from the occurrence of base metals in the form of sulphides at the base of an open excavation after the exploitation of $\mathrm{Pb}-\mathrm{Zn} \pm \mathrm{Ag}$ sulphides and As-bearing sulfosalts ores during 1973-1997, with sporadic interruptions [37]. The high sulfidation deposit in Agios Philippos Kirkis is hosted into Eocene-Oligocene volcano-sedimentary rock sequences of SE Evros and is associated with orogenic calc-alkaline to shoshonitic magmatism. This epithermal type mineralization is developed between two sub-parallel fault zones, which form the western and the eastern part of the open pit. Galena (PbS) shows the highest degree of weathering among other sulfides and sulfosalts. The low degree of oxidation of pyrite and sphalerite is reasonably explained by their rather chemical purity. Triantafyllidis [38] reported that in the upper part of the oxidation zone the predominant secondary mineral phases are sulfates, hydrosulfates and sulfoarsenates. Anglesite is the major oxidation product, followed by lower proportions of osarizawaite, beaverite, linarite, and beudantite [38]. At the lower levels of the oxidation zone, carbonates are additionally identified. Secondary carbonates include cerussite, hydrocerussite, smithsonite, azurite, and rosasite. The efflorescence appearing on the walls of the open pit is dominated by Fe-bearing (e.g., siderotile, copiapite, rhomboclase) and Cu-bearing (e.g., chalcanthite) sulfates, arsenates (scorodite) and sulfoarsenates, and much lesser $\mathrm{Pb}$ and $\mathrm{Zn}$ sulfates, indicating highly acidic and oxidative conditions. Since mine closure in 1997, an acid pit lake has been formed by infilling of the open pit by rain water and mine effluents (Figure $1 b, c$ ). The depth of the water column fluctuates, depending on the annual rainfall. The waters from the pit lake show low $\mathrm{pH}$, high Eh values, and increased concentrations of dissolved metals throughout the year [39]. 


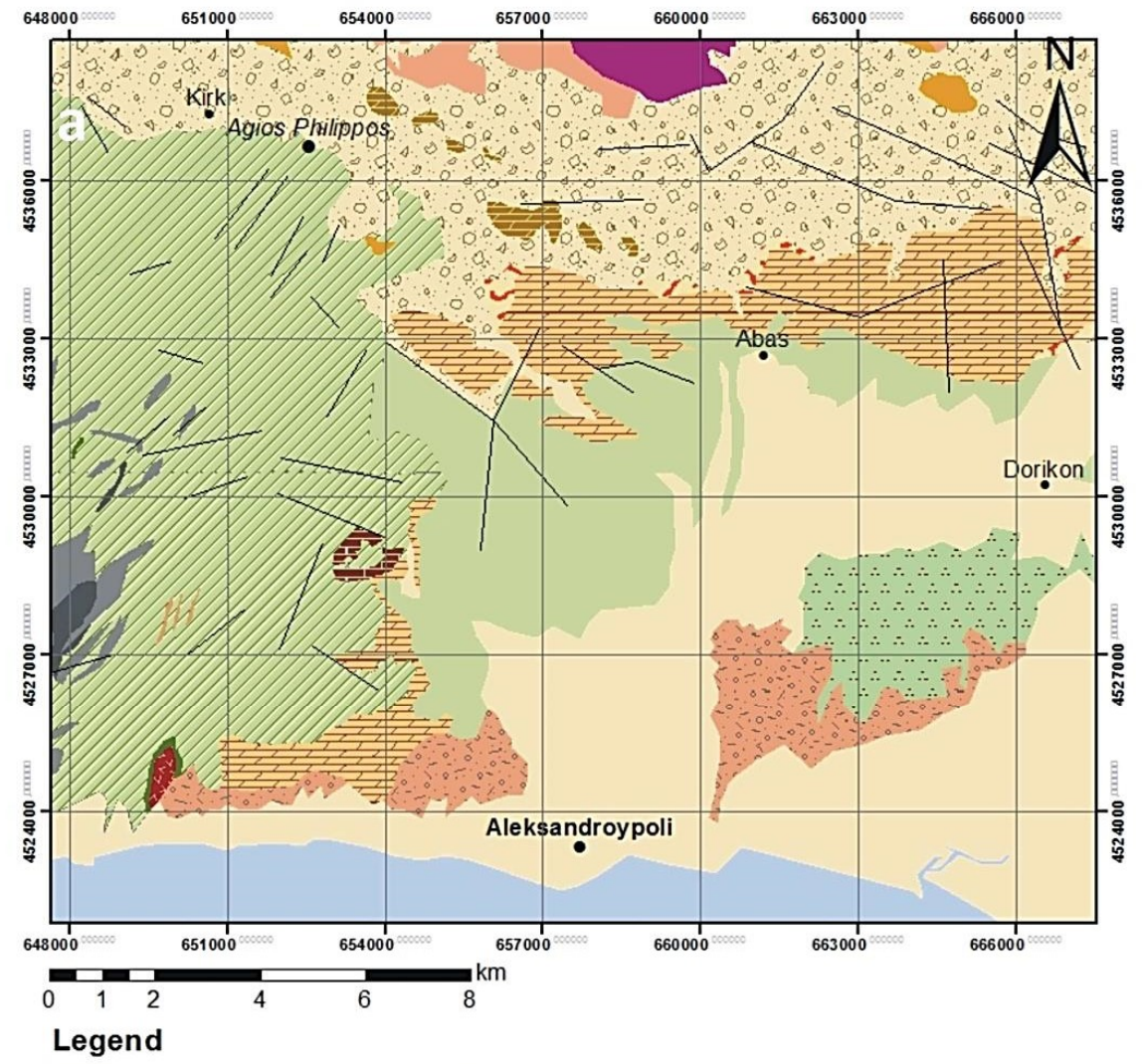

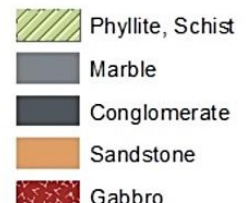

Eabbro

Amphibolitic-chloritic schist

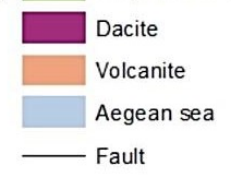

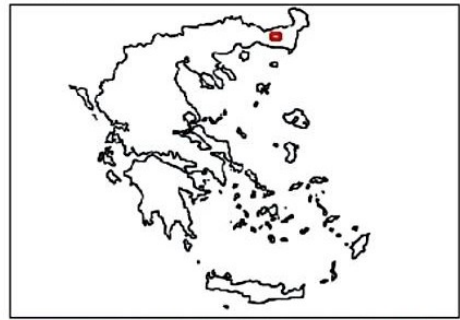
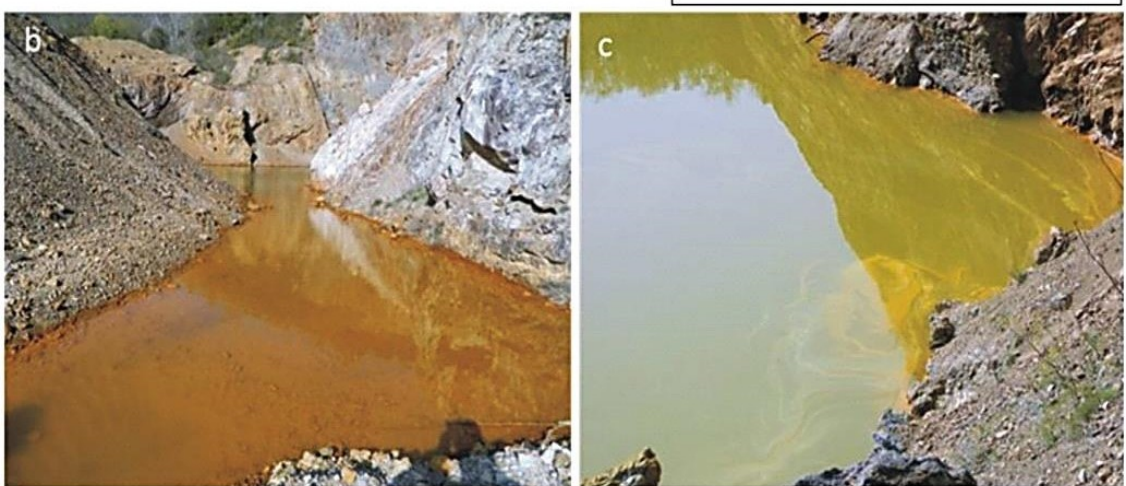

Figure 1. (a) Geological map of the Kirki region where of Agios Philippos mine is located [40]; modified after fieldwork and mapping by using ArcMap 10.1; (b,c) acidic runoff drainages in the mine of Agios Philippos (sampling area). 


\section{Materials and Methods}

\subsection{Materials}

As raw materials for the consolidation of an important acid mine drainage, mainly sterile materials were used which resulted in the execution of laboratory tests to assess such as aggregates, based on sustainable disposal and reuse of sterile materials (serpentine, andesite, magnesite, peat and biochar). The combination of mineral raw materials in sand grain size was used with a dual scope, both in the $\mathrm{pH}$ rise and in the toxic load removal of the studied drainage. More specifically, the sterile materials obtained from the Los Angeles (LA) and uniaxial compressive strength tests (UCS) which were calculated in order to be related to the mechanical strength of the produced concretes, from one selected Mg-rich ultramafic sample (serpentinized harzburgite), as well as one Pliocene volcanic rock (andesite) were used [20,21]. Moreover, a magnesium rich sample (magnesite) has also been used to remediate $\mathrm{pH}$, without being used as aggregate for industrial uses. The majority of the selected ultramafic samples were derived from the Veria-Naousa ophiolite complex, which has been intruded by Pliocene andesites [41-44]. High-quality low-carbon peat was used to adsorb heavy metals. The same peat was pyrolized at $800^{\circ} \mathrm{C} 1 \mathrm{~h}$, producing high porosity biochar agent.

\subsection{Methods}

In the present study, the polluted water and sediment was first collected from the selected area. Then the appropriate combination of mineral raw materials was chosen in order to work well in the remediation of the drainage phenomenon. As mentioned above the used mine raw materials are serpentinite, andesite, magnesite which are chosen due to their low cost and to their ability to increase $\mathrm{pH}$ values and to remediate toxic load. These mineral raw materials were examined petrographically for determining the relationships of their mineral constituents as well as their particular structural characteristics. The petrographic examination was carried out by using a polarizing optical microscope (Leica Microsystems Leitz Wetzlar, Germany). Polished blocks were prepared from the peat and the biochar samples and a semi-qualitative evaluation was performed using a Leica DMRX microscope by applying the nomenclature ICCP System 1994 [45-47]. The bulk samples as well as their clay fractions $(<2 \mu \mathrm{m})$ of the investigated samples were determined by powder X-ray diffraction (XRD), using a Bruker D8 Advance Diffractometer (Bruker, Billerica, MA, USA), with Ni-filtered CuK $\alpha$ radiation. The $<2 \mu \mathrm{m}$ clay fraction was separated by settling and dried on glass slides at room temperature. Random powder mounts were prepared by gently pressing the powder into the cavity holder. The scanning area for bulk mineralogy of the specimens covered the $2 \theta$ interval $2-70^{\circ}$, with a scanning angle step size of $0.015^{\circ}$ and a time step of $0.1 \mathrm{~s}$. For each $<2 \mu \mathrm{m}$ specimen, the clay minerals were scanned from $2^{\circ}$ to $30^{\circ} 2 \theta$ and identified from three XRD patterns (after air-drying at $25^{\circ} \mathrm{C}$, ethylene glycol solvation, and heating at $490{ }^{\circ} \mathrm{C}$ for $2 \mathrm{~h}$ ). The mineral phases were determined using the DIFFRACplus EVA 12®software (Bruker-AXS, Billerica, MA, USA) based on the ICDD Powder Diffraction File of PDF-2 2006 while the semi-quantitative analyses were performed by TOPAS $3.0 \circledR$ software (TOPAS MC Inc., Oakland, CA, USA), based on the Rietveld method refinement routine. The routine is based on the calculation of a single mineral-phase pattern according to the crystalline structure of the respective mineral, and the refinement of the pattern using a non-linear least squares routine. The quantification errors calculated for each phase according to Bish and Post [48] are estimated to be $\sim 1 \%$, while the detection limit is approximately $2 \%$.

The total porosity $\left(\mathrm{n}_{\mathrm{t}}\right)$ of the studied rocks was calculated according to ISRM [49] standard. Whole-rock chemical analyses for major and trace elements were performed at Bureau Veritas Mineral Laboratories at Vancouver (Canada). Major element analyses were carried out using an XRF (X-Ray Fluorescence) spectrometer and a sequential spectrometer (ICP-ES). Trace elements were determined on totally digested samples by inductively coupled plasma-mass spectrometry (ICP-MS) in the same laboratory. Detection limits for major and trace elements range from $0.01 \mathrm{wt} \%$ to $0.04 \mathrm{wt} \%$ 
and from $0.01 \mathrm{ppm}$ to $10 \mathrm{ppm}$, respectively. The analytical precision calculated from replicate analyses is better than $3 \%$ for most major elements and better than $5 \%$ for trace elements.

In the next stage, a new electrically continuous driven flow-through experimental device was conducted. The basic concept for the construction of the experimental electrical device was the simulation of a standard continuous water recirculation system of the treated acidic runoff, in filters with a combination of mineral raw materials. The choice of mineral raw materials closed so that both can remain effective in the remediation of the phenomenon and be feasible or easy to use without needing mineralogical separation of raw materials. After construction of the device and the selection of the raw materials, the filters were filled with the corresponding percentages, as shown in Figure 2 as well as in Table 1 . The first filter was filled with a mixture of $70 \%$ magnesite and $30 \%$ serpentinite (Figure 2a) whereas the second filter was filled with 100\% high-porosity andesite (Figure 2b). Each filling material in each filter had been crushed and sieved and a mixture of $50 \%$ sand of $1.5-0.8 \mathrm{~mm}$ grain size and 50\% sand 0.8-0.6 mm grain size was used (Figure 2c).
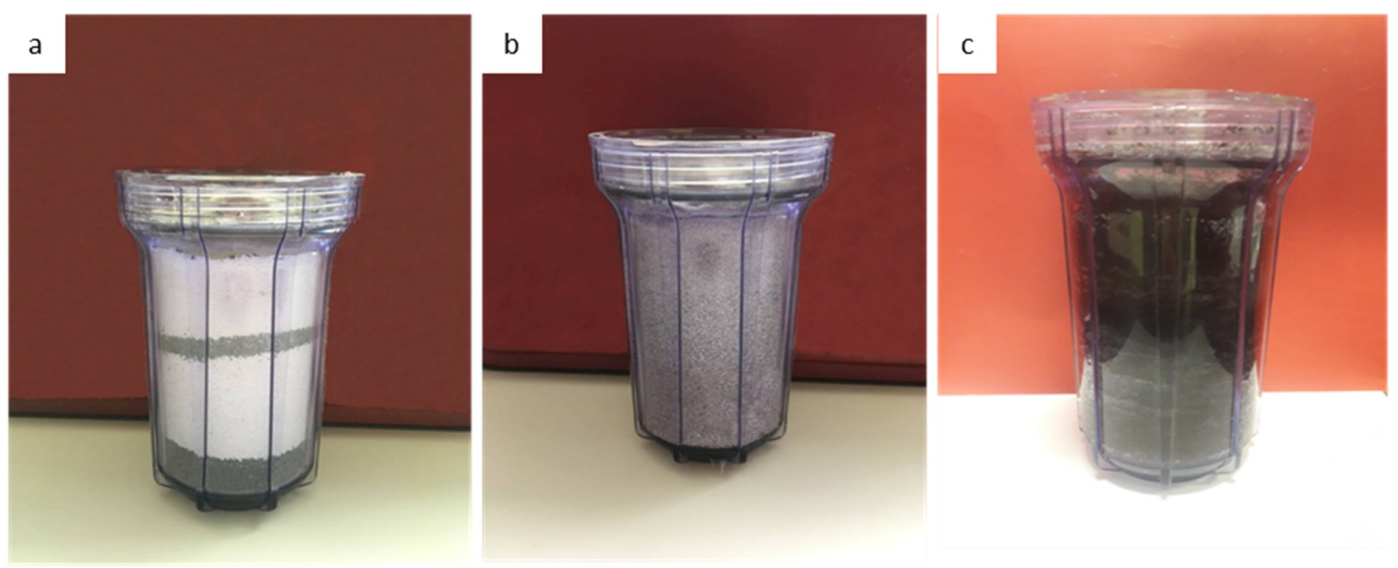

Figure 2. (a) Figure of the filter box (1 L volume) filled with sand of the serpentinite and magnesite in $30-70 \%$ proportion subsequently; (b) Figure of the filter box (1 L volume) filled with sand of andesite; (c) Figure of the filter box ( $1 \mathrm{~L}$ volume) filled with sand of the peat and the biochar in $50 \%$ proportion.

Table 1. Table showing the proportions of the raw materials used in filter boxes and the filter run time.

\begin{tabular}{ccccc}
\hline Filter & $\begin{array}{c}\text { Beginning-Pause } \\
\text { of the Operation }\end{array}$ & Sample Number & $\begin{array}{c}\text { Participation } \\
\text { Ratio in Filter }\end{array}$ & Lithotype \\
\hline \multirow{2}{*}{ Filter 1 } & 1st day-4th day & BE.01 & $30 \%$ & $\begin{array}{c}\text { serpentinite } \\
\text { magnesite }\end{array}$ \\
\hline Filter 2 & 1st day-4th day & BE.02 & $70 \%$ & andesite \\
\hline \multirow{2}{*}{ Filter 3 } & 4th day-7th day & P.1 & $100 \%$ & $\begin{array}{c}\text { peat } \\
\text { biochar }\end{array}$ \\
\hline
\end{tabular}

Furthermore, $50 \mathrm{~L}$ of waste water from the pit lake of Agios Philippos were placed into the experimental device. Then, the electric pump was put into operation where it was pumping water from the first tank and was draining water through filter boxes 1 and 2 into the tanks 1 and 3 , and as a result tanks 1 and 3 feed tanks 2 and 4 due to communicating vessels (Figures 3 and 4). In the deposits 3 and 4 where the water was led after the two filters, oxygen was continuously pumped to the bottom through air pumps. From the beginning of the experimental process periodic measurements of $\mathrm{pH}$ values of water were made. When the $\mathrm{pH}$ value exceeded 6.5, a third filter was manually operated, stopping the operation of the first two, modifying the system with the cocks accordingly (Figures 3 and 4). This third filter box was filled with $50 \%$ of its volume with compressed peat and the remaining $50 \%$ with biochar, which resulted after pyrolysis at $800{ }^{\circ} \mathrm{C}$ for two hours (Figures 3 and 4 ). 


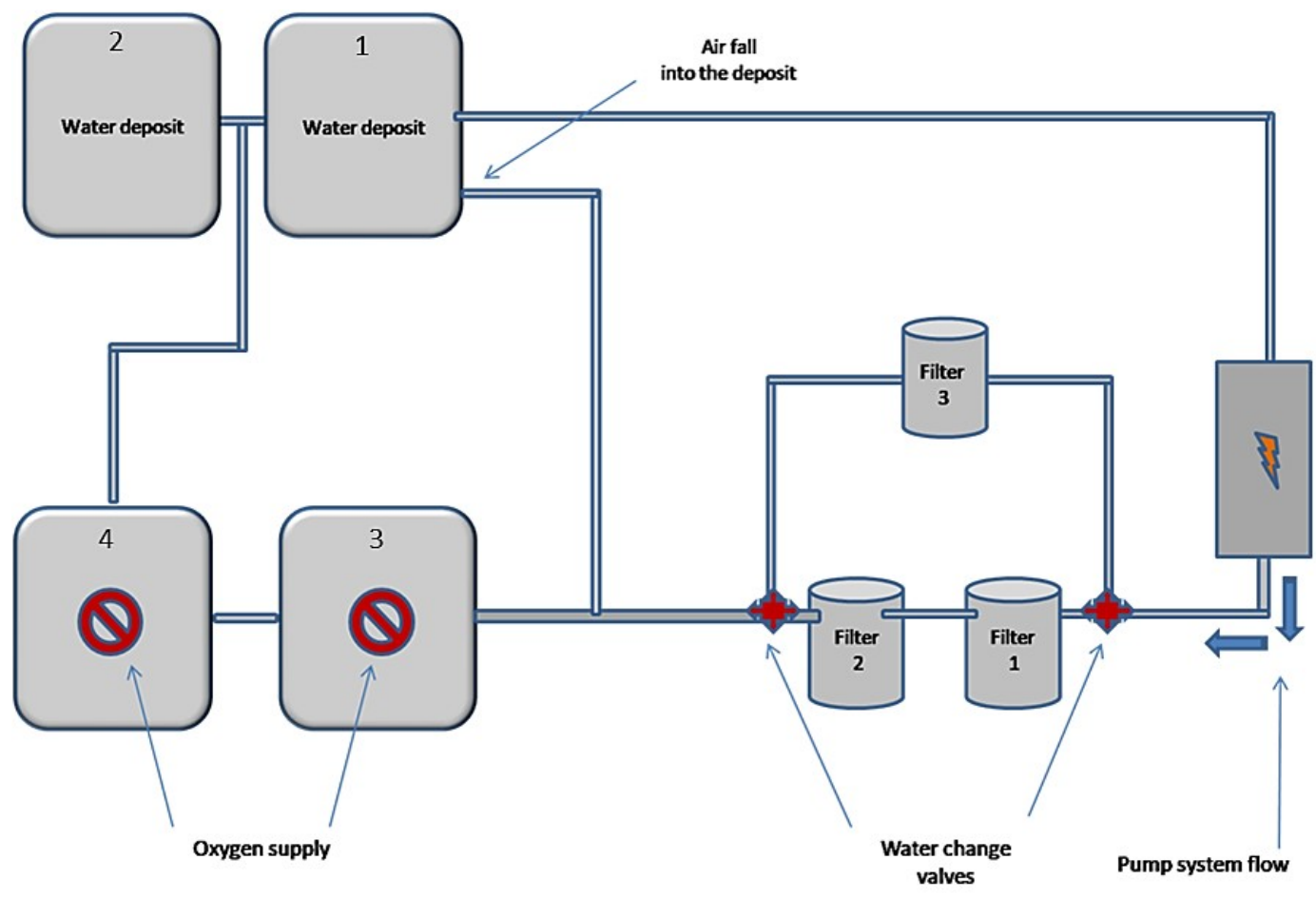

Figure 3. Schematic representation of the experimental device.

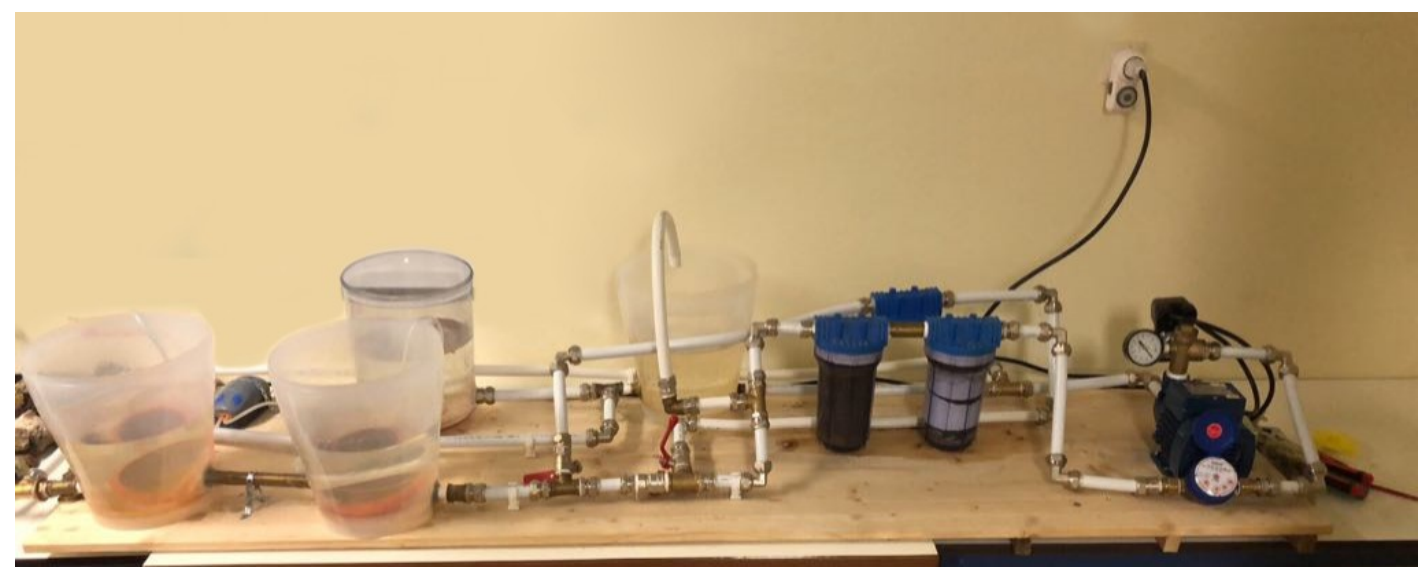

Figure 4. The experimental electrically driven forced device.

Biochar is called the solid, carbon-rich, product of the thermal decomposition of biomass under conditions of limited presence or total absence of oxygen (pyrolysis). The solid product of which was used as a filter, called biochar, and shows enrichment of elemental carbon in contrast to the original peat $[50,51]$.

During the experimental process, sporadic samples of water were taken for geochemical analysis which it took place after the completion of the experimental process. Water samples were filtered with a lab filter paper of $0.10-0.45 \mu \mathrm{m}$ diameter, before geochemical analysis to remove suspended and colloidal particles. The geochemical analyses were carried out in the Department of Geology of the University of Patras with conjugated plasma argon mass spectrometry (ICP-MS). The experiment lasted for a total of 7 days, while the device remained covered all the way so as to prevent any water evaporation. 


\section{Results}

\subsection{Petrographic Features of Rock Materials}

The serpentinite is characterized by cataclastic texture. Its primary mineralogical assemblage includes relics of porphyroclasts of orthopyroxene, $\mathrm{Cr}$-spinel, as well as rare olivine and clinopyroxene (Figure 5a,b). Serpentine is the dominant secondary phase showing typical mesh and locally bastite textures. Chlorite and magnetite are also products of hydrothermal alteration. Brittle deformation is expressed mainly by intense fragmentation of spinel, as well as by intragranular microcracks. The collected andesite presents porphyritic texture with phenocrysts of plagioclase, K-feldspar, biotite and lesser clinopyroxene surrounded by a microcrystalline and amorphous groundmass (Figure 5c,d). Plagioclase phenocrysts are optically zoned showing both normal and oscillatory reverse zoning. Accessory minerals include apatite, titanite, zircon, and magnetite. Alteration products in the andesite include clay minerals such as smectite and illite, albite, chlorite, Fe-oxides, and calcite. Magnesite is restricted to white-coloured veins within serpentinite bodies in the Veria-Naousa ophiolite. It displays a microcrystalline and cryptocrystalline structure (Figure 5e,f). The primary assemblage mainly consists of magnesite (>90\%). Accessory minerals include serpentine, chlorite, talc, quartz, and calcite.
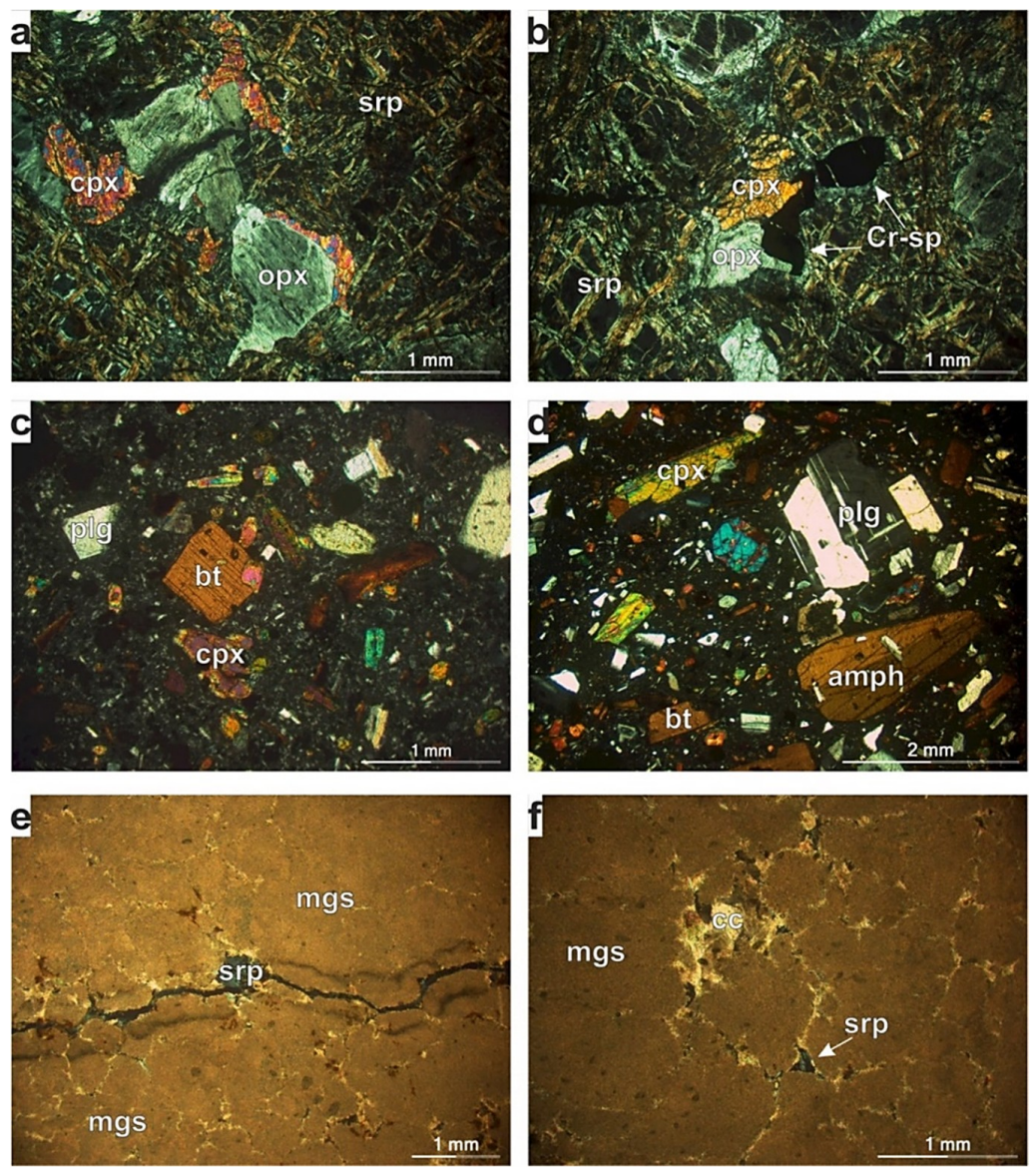

Figure 5. Photomicrographs of rock materials showing: $(\mathbf{a}, \mathbf{b})$ serpentinite with relics of orthopyroxene, clinopyroxene and Cr-spinel surrounded serpentinized matrix (sample BE.01*, XPL); (c,d) porphyritic andesite with phenocrysts of plagioclase, clinopyroxene, amphibole and biotite in a microcrystalline to glassy groundmass (sample BE.82*, XPL); (e,f) magnesite with cryptocrystalline texture and accessory serpentine and calcite (sample BE.02, XPL); cpx: clinopyroxene, opx: orthopyroxene, srp: serpentine, Cr-sp: Cr-spinel, plg: plagioclase, bt: biotite, amph: amphibole, mgs: magnesite, cc: calcite; * = previously published samples by Petrounias et al. [36]. 


\subsection{Petrographic Features of Peat and Biochar}

The utilized peat is a commercial sphagnum peat produced for horticulture purposes. The ash yield is $2.1 \mathrm{wt} \%$ indicating a very high grade, while the organic petrographical observations revealed the predominance of partially humified and non-gelified tissues, in the form mainly of pre-textinite, whereas textinite occurred subordinately (Figure 6a-f). Texto-ulminite and attrinite, as well as corpohuminite and cutinite were also observed, but much less frequently. The semi-quantitative evaluation of the applied peat revealing the predominance of structured macerals coincides to the sphagnum-origin of this material [52]. Additionally, this kind of peat is poor in mineral matter; it very rarely displays high humification and/or gelification, something that would have enhanced their capacity as absorbents through the formation of humic acids, hence the predominance of fresh tissues and pre-textinite (i.e., cellulose remnants) indicate the significant unaltered nature of the peat.
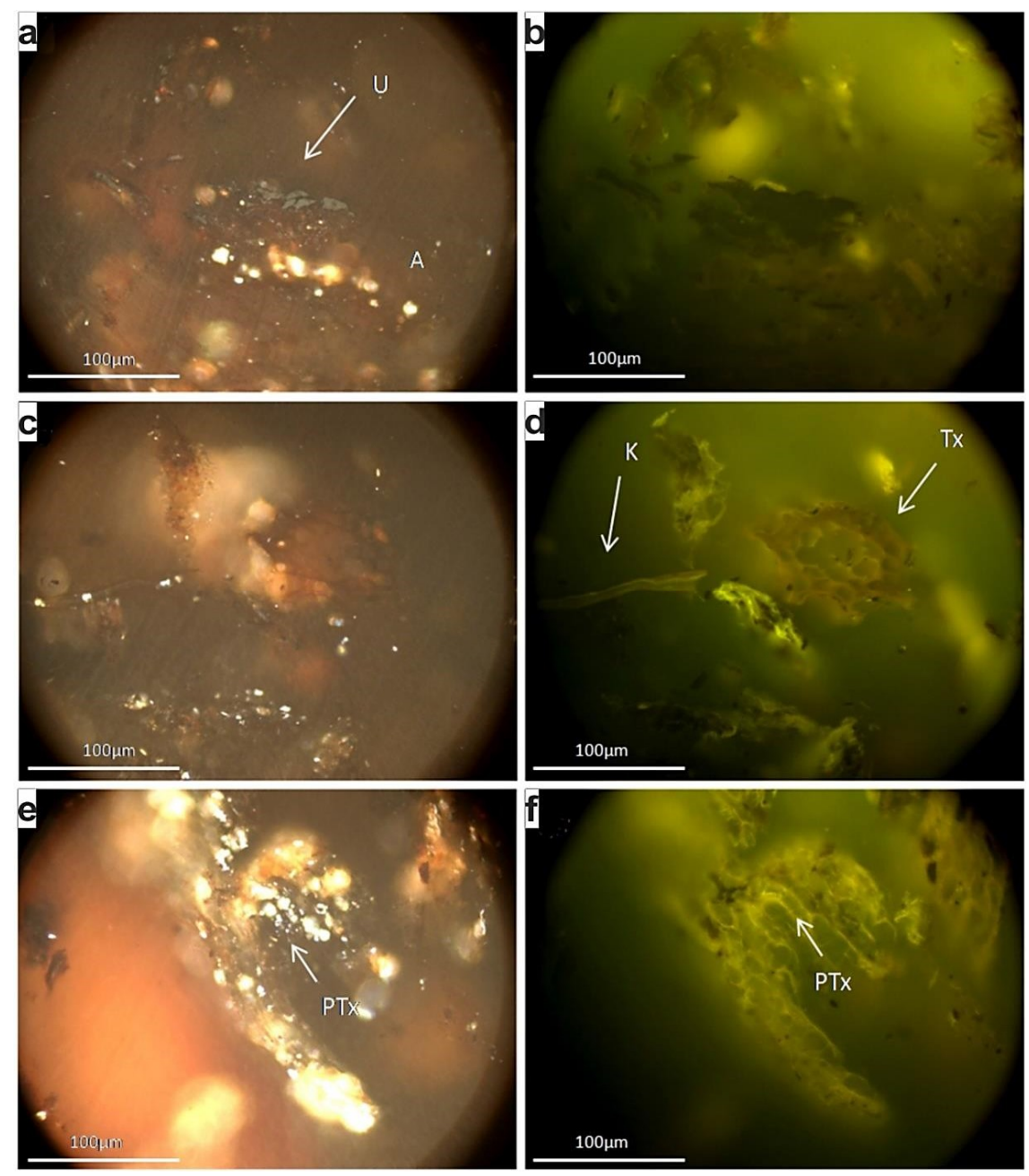

Figure 6. Photomicrographs of the peat polished block; imaging under white reflected $(\mathbf{a}, \mathbf{c}, \mathbf{e})$ and blue light excitation $(\mathbf{b}, \mathbf{d}, \mathbf{f})$, using oil objective and X50 magnification: A: attrinite, U: ulminite, C: cutinite, Tx: textinite, PTx: pre-textinite.

The charring of the peat produced a bio-char, which is almost entirely composed by chars in the form of inertoids [45] (Figure 7).

The SEM study confirms the fibric and rich in cellulose remnants ungelified nature of the applied peat, and hence the limited porosity in comparison to the charring product (Figure 8), which exhibits a quite uniform distribution of pores and subsequent an increased specific area. 

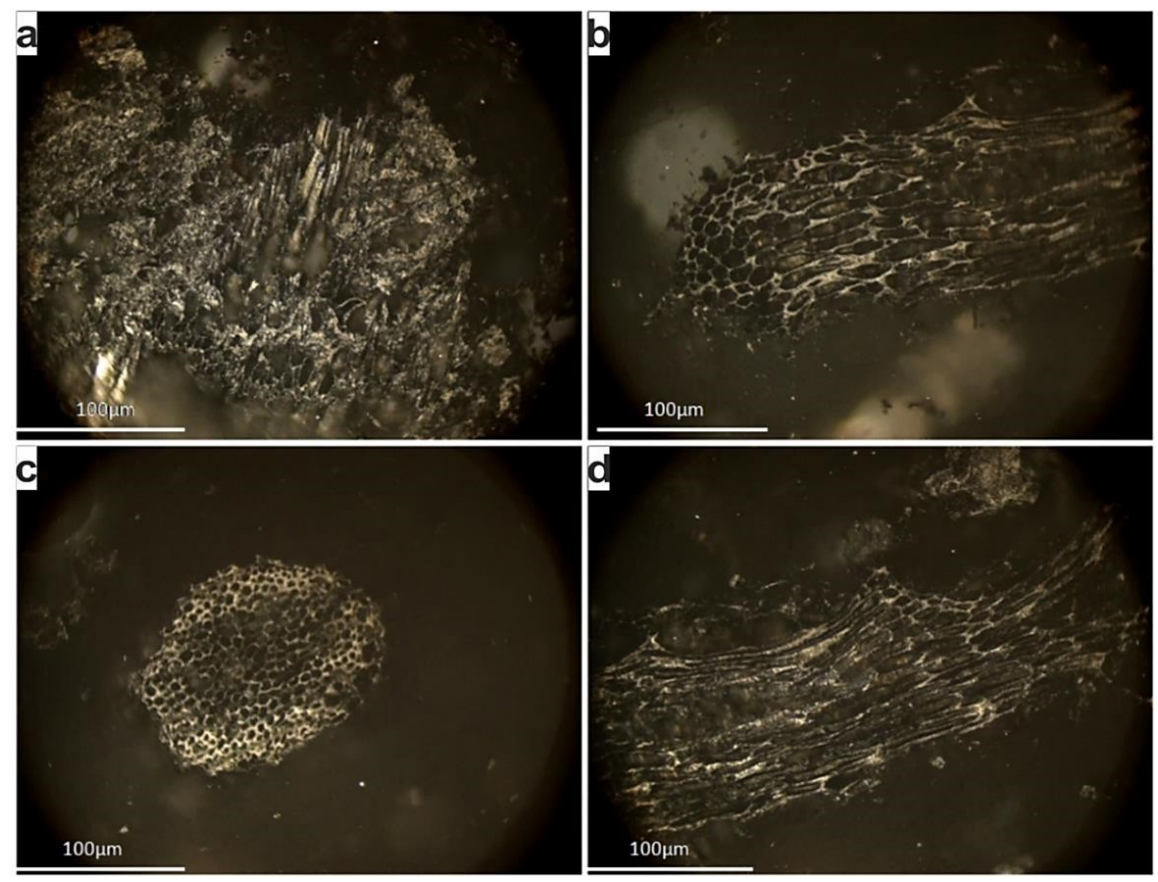

Figure 7. Photomicrographs of the biochar polished block; imaging under white reflected, using oil objective and X50 magnification. All the particles represent inertoid (fusinoid) chars.
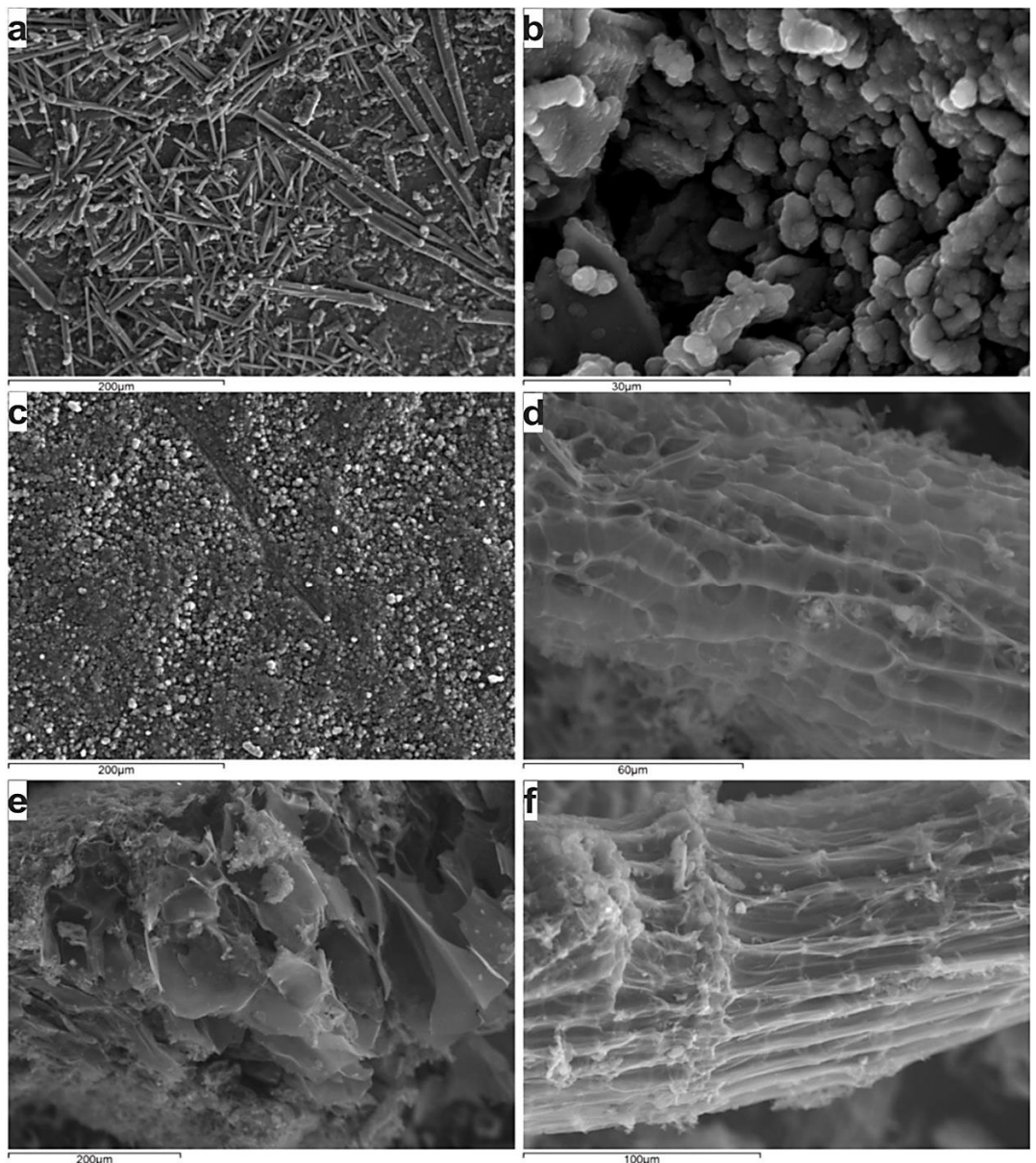

Figure 8. Backscattered electron images showing the fibric nature of the peat sample $(\mathbf{a}-\mathbf{c})$ and the occurrence of primary porosity, whereas the secondary porosity has been developed in the inertoids (d-f). 


\subsection{X-ray Diffractometry of Raw Materials}

The crystalline assemblage of the studied raw materials was also identified with the aid of XRD (Figure $9 a-f$ ). The X-ray diffraction enabled us to identify the crystalline phases of the studied raw materials (Figure $9 \mathrm{a}-\mathrm{c}, \mathrm{f}$ ). In addition the produced broad area, especially in the region of $15-35^{\circ} 2 \theta$ in XRD patterns of Peat and biochar (Figure 9d,e respectively) indicates their organic carbon matrix and quartz indicated by a peak in biochar pattern. In this case study, for the accurate identification of the type of clay minerals in the studied andesite sample, the samples were size fractionated and studied after ethylene-glycol and thermal treatment (Figure 9f). The obtained compositions are consistent with our petrographic observations under the polarizing microscope.
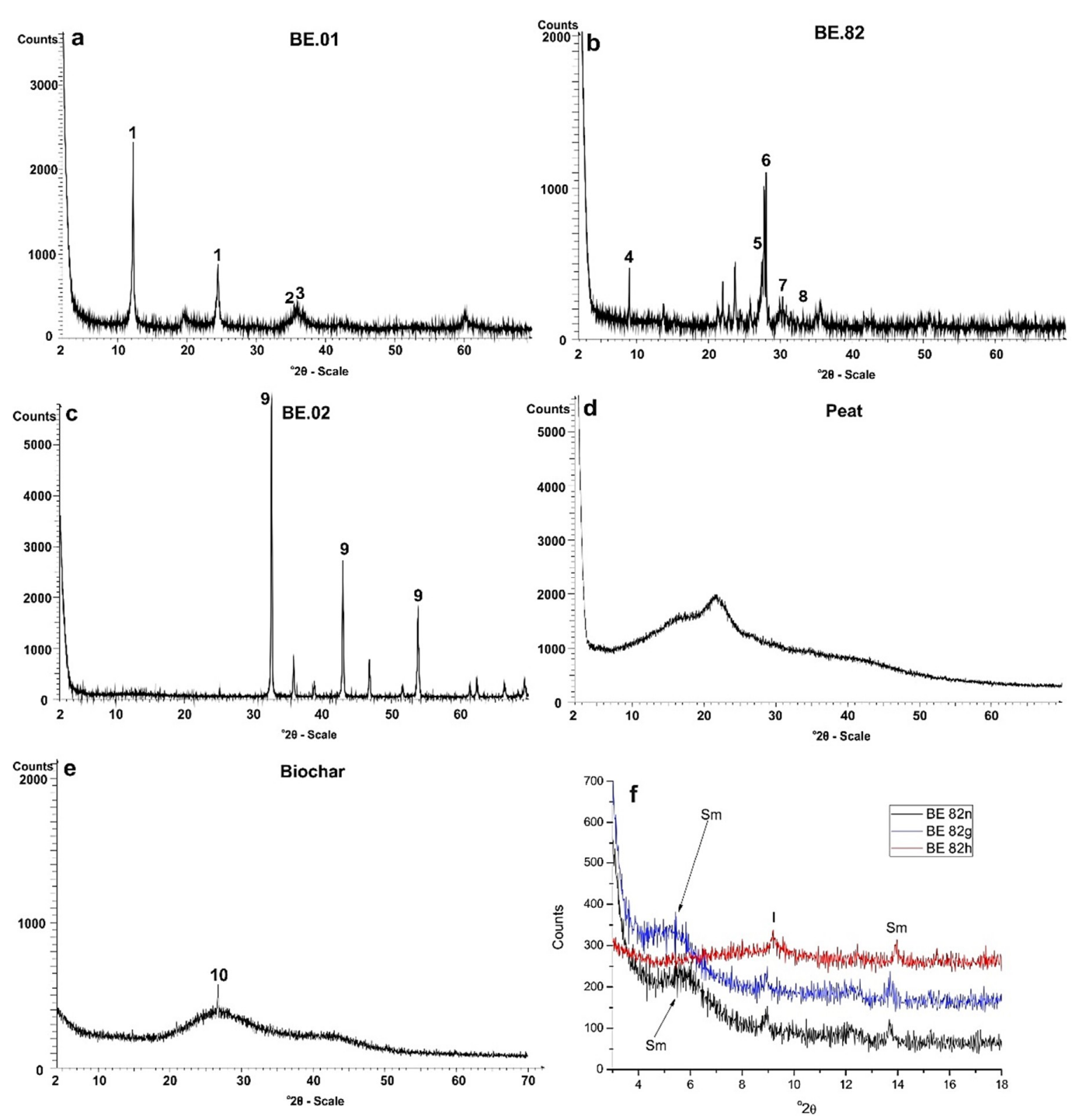

Figure 9. XRD patterns of the studied mineral raw materials (a-e). Sample numbers are indicated as insets (1: serpentine, 2: magnetite, 3: spinel, 4: mica, 5: K-feldspar, 6: plagioclase, 7: diospide, 8: hematite, 9: magnesite, 10: quartz); (f) X-ray diffraction patterns of the clay fraction from andesite (BE.82). Sample number is given in the inset (n: air dried, g: glycolated, t: heated, Sm: smectite, I: Illite).

\subsection{Total Porosity of Rock Materials}

The calculated total porosity $\left(\mathrm{n}_{\mathrm{t}}\right)$ values for the investigated rocks ranges from $1.32 \%$ in the magnesite through $6.46 \%$ in the serpentinized harzburgite to 10.76 in the andesite (Table 2). 
Table 2. Total porosity values of the rock materials.

\begin{tabular}{cc}
\hline Lithotype & Total Porosity $\left(\left(\mathbf{n}_{\mathbf{t}}\right) \mathbf{\%}\right)$ \\
\hline Serpentinite (BE.01) & 6.49 \\
Andesite (BE.82) & 10.76 \\
Magnesite (ED.18) & 1.32 \\
\hline
\end{tabular}

\subsection{Whole-Rock Geochemical Analysis of Rock Materials}

Major and trace elements data from the serpentinite, andesite and magnesite from the Veria-Naousa ophiolite area are listed in Table 3. The serpentinite has higher $\mathrm{Fe}_{2} \mathrm{O}_{3}, \mathrm{Cr}, \mathrm{Ni}$, Co and lower $\mathrm{Ba}$ and $\mathrm{Sr}$ contents relative to the other lithotypes. It is characterized by high contents of $\mathrm{MgO}$ and loss on ignition (LOI) due to extensive serpentinization. The andesite displays higher $\mathrm{CaO}$, $\mathrm{SiO}_{2}, \mathrm{Al}_{2} \mathrm{O}_{3}, \mathrm{~Pb}$ and alkali contents, whereas $\mathrm{MgO}$ and $\mathrm{Ni}$ contents are lower. The magnesite has typically the highest contents in $\mathrm{MgO}$ and LOI and the lowest contents in $\mathrm{SiO}_{2}, \mathrm{~Pb}$ and $\mathrm{Zn}$ than the others lithotypes.

Table 3. Representative geochemical analyses of rock materials from Veria-Naousa ophiolite complex (-: below detection limit, ${ }^{\mathrm{t}}$ : total).

\begin{tabular}{|c|c|c|c|}
\hline Sample & BE.01 & BE.82 & BE.02 \\
\hline Rock-Type & Serpentinite & Andesite & Magnesite \\
\hline \multicolumn{4}{|c|}{ Major Elements (wt \%) } \\
\hline $\mathrm{SiO}_{2}$ & 39.82 & 56.39 & 0.3 \\
\hline $\mathrm{TiO}_{2}$ & - & 0.63 & - \\
\hline $\mathrm{Al}_{2} \mathrm{O}_{3}$ & 1.01 & 17.84 & - \\
\hline $\mathrm{Fe}_{2} \mathrm{O}_{3}{ }^{\mathrm{t}}$ & 8.86 & 5.91 & - \\
\hline $\mathrm{MnO}$ & 0.11 & 0.09 & \\
\hline $\mathrm{MgO}$ & 34.17 & 2.25 & 47.06 \\
\hline $\mathrm{CaO}$ & 0.10 & 5.28 & 0.42 \\
\hline $\mathrm{Na}_{2} \mathrm{O}$ & - & 3.78 & - \\
\hline $\mathrm{K}_{2} \mathrm{O}$ & - & 4.80 & - \\
\hline $\mathrm{P}_{2} \mathrm{O}_{5}$ & - & 0.39 & - \\
\hline LOI & 14.6 & 2.0 & 51.4 \\
\hline Total & 98.67 & 99.36 & 99.22 \\
\hline \multicolumn{4}{|c|}{ Trace Elements (ppm) } \\
\hline $\mathrm{Cr}$ & 2963 & - & - \\
\hline $\mathrm{Co}$ & 91.1 & 17.3 & 0.6 \\
\hline $\mathrm{Ni}$ & 2655.8 & 11.6 & 409.8 \\
\hline $\mathrm{Cu}$ & 12.9 & 29.5 & 0.6 \\
\hline $\mathrm{Zn}$ & 8 & 26 & 2 \\
\hline $\mathrm{Rb}$ & 0.4 & 203.5 & 0.3 \\
\hline $\mathrm{Sr}$ & 2.0 & 1896.2 & 5.2 \\
\hline $\mathrm{Y}$ & 0.9 & 27.0 & - \\
\hline $\mathrm{Zr}$ & 0.1 & 290.5 & - \\
\hline $\mathrm{Nb}$ & 0.3 & 20.6 & - \\
\hline $\mathrm{Pb}$ & 21.7 & 50.0 & 4.2 \\
\hline $\mathrm{Ba}$ & 1 & 2020 & 3 \\
\hline $\mathrm{V}$ & 60 & 115 & - \\
\hline Sc & 11 & 12 & - \\
\hline $\mathrm{Ga}$ & 3.1 & 20.0 & - \\
\hline Hf & - & 7.4 & - \\
\hline As & 7.2 & 8.9 & - \\
\hline $\mathrm{Hg}$ & - & - & - \\
\hline $\mathrm{Ta}$ & - & 1.2 & - \\
\hline Th & - & 62.7 & - \\
\hline $\mathrm{U}$ & 0.2 & 17.8 & - \\
\hline $\mathrm{Be}$ & - & 4 & - \\
\hline $\mathrm{Au}(\mathrm{ppb})$ & 3.4 & 1.0 & 0.9 \\
\hline
\end{tabular}




\subsection{Chemical Composition of the Sludge}

Samples were collected from the sludge precipitated at the bottom of the pit lake in April 2016. Geochemical analysis was performed in the sludge in order to investigate and evaluate the charge of the heavy element in the acid mine effluents and the results are listed below in Table 4.

Table 4. Results of geochemical analyses of the sediment sample deriving from the Agios Philippos mine.

\begin{tabular}{cccccccccccc}
\hline $\begin{array}{c}\mathbf{S} \\
(\mathbf{p p m})\end{array}$ & $\begin{array}{c}\text { Fe } \\
(\mathbf{p p m})\end{array}$ & $\begin{array}{c}\mathbf{P d} \\
(\mathbf{p p m})\end{array}$ & $\begin{array}{c}\mathrm{Zn} \\
(\mathbf{p p m})\end{array}$ & $\begin{array}{c}\mathrm{Cu} \\
(\mathbf{p p m})\end{array}$ & $\begin{array}{c}\mathrm{Cd} \\
(\mathbf{p p m})\end{array}$ & $\begin{array}{c}\text { Mn } \\
(\mathbf{p p m})\end{array}$ & $\begin{array}{c}\text { Ni } \\
(\mathbf{p p m})\end{array}$ & $\begin{array}{c}\mathbf{A g} \\
(\mathbf{p p m})\end{array}$ & $\begin{array}{c}\mathbf{C r} \\
(\mathbf{p p m})\end{array}$ & $\begin{array}{c}\text { Co } \\
(\mathbf{p p m})\end{array}$ & $\begin{array}{c}\text { Sb } \\
(\mathbf{p p m})\end{array}$ \\
\hline 32,485 & 31,200 & 4801 & 3720 & 1382 & 27 & 1053 & 25 & 10 & 4 & 2.19 & 26.87 \\
\hline
\end{tabular}

\subsection{Results of the Remediation of the Industrial Waste Water during the 7-Day Operation}

In the experimental electrical device the combined use of sterile mineral raw materials such as serpentinite, andesite, magnesite, peat and biochar in portions mentioned in Table 1 as remediation agents of the acidic effluents of the selected lake with continuous water circulation, was evaluated. The variation of the $\mathrm{pH}$ values during the operation of the experiment is listed in Table 5. The $\mathrm{pH}$ values showed a continuously increasing trend from the first till the fourth day of the experiment, when $\mathrm{pH}$ reached the maximum value of 6.93. The infection of the $\mathrm{pH}$ curve after the fourth day indicates a general stability of $\mathrm{pH}$ at slightly reduced values of around 6.5-6.8 maintaining a steady trend with very small fluctuations. The temperature of the solution showed a significant increase of $8.6^{\circ} \mathrm{C}$, after the fourth day, which cannot be attributed to an increase in the temperature of the mechanical equipment of the device (Table 5). This temperature rise is probably due to oxidation of the organic matter in the presence of oxygen provided in the device.

Table 5. Results of geochemical analyses of the sediment sample deriving from the Agios Philippos mine.

\begin{tabular}{|c|c|c|c|c|c|c|c|c|c|c|}
\hline Day & $\begin{array}{c}\text { 1st } \\
\text { Day } \\
(11: 00)\end{array}$ & $\begin{array}{c}\text { 1st } \\
\text { Day } \\
(14: 30)\end{array}$ & $\begin{array}{c}\text { 1st } \\
\text { Day } \\
(15: 00)\end{array}$ & $\begin{array}{l}\text { 2nd } \\
\text { Day }\end{array}$ & $\begin{array}{l}\text { 3rd } \\
\text { Day }\end{array}$ & $\begin{array}{c}\text { 4th } \\
\text { Day } \\
(10: 00)\end{array}$ & $\begin{array}{c}\text { 4th } \\
\text { Day } \\
(19: 00)\end{array}$ & $\begin{array}{l}5 \text { th } \\
\text { Day }\end{array}$ & $\begin{array}{l}\text { 6th } \\
\text { Day }\end{array}$ & $\begin{array}{l}\text { 7th } \\
\text { Day }\end{array}$ \\
\hline $\mathrm{pH}$ & 2.99 & 3.79 & 4.70 & 6.04 & 6.45 & 7.13 & 6.65 & 6.57 & 6.54 & 6.82 \\
\hline $\mathrm{T}_{\text {water }}\left({ }^{\circ} \mathrm{C}\right)$ & 25.2 & 26.0 & 29.0 & 28.0 & 29.0 & 37.6 & 37.8 & 39.8 & 38.0 & 37.6 \\
\hline
\end{tabular}

The results of the geochemical analyses of water per day of operation of the experimental array are presented in Table 6. The initially highly charged solution, derived from the acid drainage, has a gradual decontamination of the heavy metals content during the 7-day operation of the device. Notable decreases of certain heavy elements $(\mathrm{Zn}, \mathrm{Pb}, \mathrm{Cu}, \mathrm{U}$, and $\mathrm{Fe}$ ) are observed after the fourth day of the experiment when the third filter was involved in the operation and when $\mathrm{pH}$ reached the value of 6.5. As on the fourth day of operation and thereafter the active period of operation of the device with regard to $\mathrm{Zn}$ binding was observed fulfilling the basic objective of optimal performance of the process of adsorption of heavy metals within the multiple resources at one of the available adsorption sites. The filter is put into operation after the $\mathrm{pH}$ value of the solution exceeded the value 6.5. By forced flow, the main volume of the solution was transferred to the boundary layer of the fixed surface layer surrounding this adsorbent. 
Table 6. Results of water chemical analyses per day of operation of the second experimental continuous device (- below detection limit).

\begin{tabular}{|c|c|c|c|c|c|c|c|c|c|}
\hline $\begin{array}{c}\text { Days of Sampling } \rightarrow \\
\text { Elements } \\
\text { (ppb) } \downarrow\end{array}$ & $\begin{array}{c}\text { 1st } \\
\text { Water Analysis at the } \\
\text { Beginning (Time: 11:00) }\end{array}$ & $\begin{array}{c}\text { 1st } \\
\text { (Time: 15:00) }\end{array}$ & $\begin{array}{c}\text { 2nd } \\
\text { (Time: 11:00) }\end{array}$ & $\begin{array}{c}\text { 2nd } \\
\text { (Time: 15:00) }\end{array}$ & 3 rd & 4 th & 5 th & 6th & 7th \\
\hline $\mathrm{Ag}$ & 0.18 & 0.19 & 0.12 & 0.75 & 0.15 & 0.66 & 0.09 & 0.08 & 0.14 \\
\hline As & - & - & 1.49 & 1.37 & 0.81 & - & 1.21 & 1.25 & - \\
\hline Ba & 20.54 & 26.31 & 120.65 & 78.56 & 86.09 & 88.12 & 86.62 & 90.88 & 71.86 \\
\hline $\mathrm{Be}$ & 24.11 & 18.46 & 0.65 & 1.31 & 1.27 & 1.17 & 1.39 & 1.38 & 1.30 \\
\hline $\mathrm{Cd}$ & 1717.73 & 1806.63 & 1943.44 & 1827.29 & 1840.01 & 1779.79 & 1802.34 & 1887.21 & 1995.75 \\
\hline Co & 213.11 & 234.75 & 209.71 & 160.83 & 166.05 & 158.24 & 175.00 & 186.58 & 198.51 \\
\hline $\mathrm{Cr}$ & - & - & 17.39 & 18.51 & - & - & - & - & - \\
\hline Cs & 13.70 & 11.41 & 24.48 & 22.35 & 23.71 & 23.19 & 25.62 & 27.23 & 29.97 \\
\hline $\mathrm{Cu}$ & 8847.21 & 9038.43 & 74.62 & 67.88 & 88.58 & 79.72 & 65.12 & 45.73 & 35.10 \\
\hline $\mathrm{Ga}$ & 3.90 & 4.38 & 4.71 & 3.74 & 3.85 & 3.90 & 3.68 & 3.89 & 3.19 \\
\hline $\mathrm{Li}$ & 25.96 & 26.82 & 48.17 & 28.01 & 29.96 & 28.75 & 38.75 & 40.62 & 40.43 \\
\hline $\mathrm{Mn}$ & $70,982.00$ & $75,014.04$ & $79,519.93$ & $62,665.14$ & $65,927.83$ & $64,350.15$ & $73,595.50$ & $78,936.65$ & $84,328.29$ \\
\hline $\mathrm{Pb}$ & 812.77 & 329.79 & 88.58 & 37.01 & 43.93 & 30.71 & 23.27 & 20.46 & 19.94 \\
\hline $\mathrm{Rb}$ & 60.42 & 47.28 & 44.67 & 43.71 & 46.72 & 45.55 & 32.50 & 25.28 & 11.11 \\
\hline $\mathrm{Sr}$ & 520.57 & 460.55 & 957.43 & 972.86 & 1025.03 & 1001.78 & 1169.42 & 1261.13 & 1330.17 \\
\hline V & - & - & - & 13.17 & 4.60 & - & - & - & - \\
\hline $\mathrm{U}$ & 111.96 & 113.76 & 0.07 & 0.17 & 0.49 & 0.00 & 0.04 & 0.00 & 0.00 \\
\hline $\mathrm{Zn}$ & $285,458.55$ & $302,248.01$ & $224,694.59$ & $177,796.45$ & $168,876.79$ & $145,508.28$ & $123,173.02$ & $75,591.12$ & $50,157.35$ \\
\hline Se & 24.91 & 21.10 & 18.89 & 16.77 & 13.94 & 13.36 & 16.43 & 15.74 & 20.69 \\
\hline $\mathrm{Ni}$ & 1149.40 & 1227.28 & 1715.19 & 2492.34 & 2776.00 & 2959.62 & 3446.81 & 3651.29 & 3627.29 \\
\hline $\mathrm{Fe}$ & 6149.02 & 7230.94 & 3368.72 & 2414.98 & 2340.99 & 2300.44 & 2298.15 & 1800.93 & 1300.57 \\
\hline
\end{tabular}




\section{Discussion}

Pit lakes or mining lakes constitute severe environmental problems, hence research objects for many scientists which have studied the use of mineral raw materials such as magnesite, dunite and serpentinite as well as natural and organic materials such as peat and biochar to remediate drainage waste waters $[18,53,54]$. In this study, the remediation of polluted water was attempted in a continuous driven flow forced device by using sterile aggregates and other low-cost materials. This method it is possible to simulate the field conditions in the optimal way.

\subsection{Remediation of $p H$ Values Using the Proposed Experimental Continuous Flow Device}

Regarding the $\mathrm{pH}$ adjustment, the experimental device was particularly effective. This happened due to the participation of magnesite and serpentinite which were very effective in $\mathrm{pH}$ remediation [18]. The adjustment of $\mathrm{pH}$ values was one of the main goals of the studied device, as it is one of the most important factors affecting the concentration and mobility of various heavy metals in solutions. The use of magnesium-rich rocks in various environmental uses has been reported by many researchers [55]. For several years, powdered olivine has been used to remediate various environmental problems, mainly used as acid water regulators. The use of olivine powder results in a smooth increase of $\mathrm{pH}$ in contrast to the case of using limestone powder, which results in a sharp increase of $\mathrm{pH}$, thus creating additional problems in the wider ecosystem of the lakes because of the shock. In this study, the serpentinite (BE.01) may release magnesium ions while also engaging more $\mathrm{H}^{+}$. The increase in $\mathrm{pH}$ can be attributed mainly to the adsorption of $\mathrm{H}^{+}$cations on the surface of serpentine crystals as the structure of serpentine consists of silicon tetrahedral which are combined with magnesium. In such acidic conditions, the $\mathrm{Mg}-\mathrm{O}$ bonds decompose, thereby completely destroying the serpentine structure, and hence $\mathrm{Mg}^{2+}$ and silicate tetrahedral $\left(\mathrm{SiO}_{4}{ }^{4-}\right)$ are released in the solution. Similar conclusions been reported by Crundweel [56] investigating the interaction between forsterite and acid solutions, which reported that $\mathrm{H}^{+}$ions react superficially with silicon $\left(\mathrm{SiO}_{4}{ }^{4-}\right)$ and $\mathrm{H}_{2} \mathrm{O}$ surface-reacts with $\mathrm{Mg}$. The same researcher also notes that this surface reaction leads to polymerization of the isolated silicon tetrahedral allowing the protons to penetrate or adsorb on the surface of the Mg-rich crystals by neutralizing the $\mathrm{pH}$ of the solution. Moreover, the studied serpentinite presents an important advantage in contrast to other lithotypes concerning the specific reaction surface. As shown in the graph of Figure 10, the solution through the filter flow is in contact with the serpentinized peridotite, the surface adsorbed particles of the solution are transferred through the macropores to the mesopores and finally through the dense network of the cells enters the set of micropores between superficial internal structures. Sterile andesitic aggregates were also used which were considered as capable for satisfactory filtration due to their high total porosity values. Properties of the used mineral raw materials seem to have contributed to the optimum efficiency of the proposed experimental device.

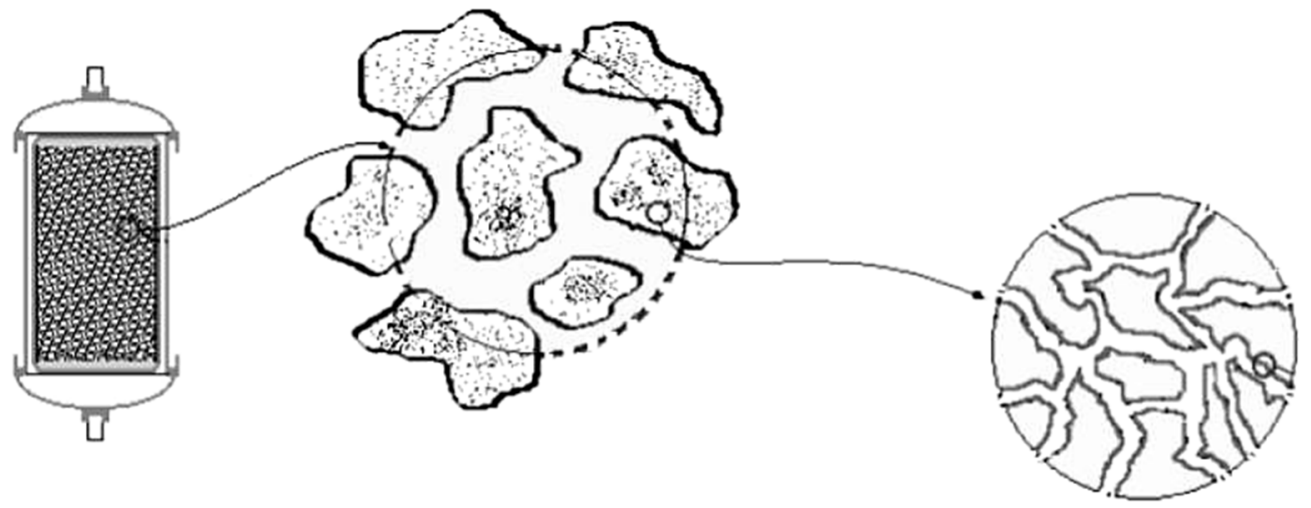

Figure 10. Schematic representation of the structure of the micropores of the serpentinite which is used as raw material in the filter boxes in the experiment of the present study. 
Moreover, magnesite has drastically impacted on the neutralization of the tested acid solution. This is due to the fact that when $\mathrm{MgCO}_{3}$ comes into contact with water the ions $\left(\mathrm{Mg}^{2+}\right.$ and $\left.\mathrm{CO}_{3}{ }^{2-}\right)$ of its grid are partially dissolved. When the ions of its grid are dissolved, hydrolysis of cations is carried out, producing $\mathrm{MgOH}^{+}$and $\mathrm{Mg}(\mathrm{OH})_{2}$. The anion is subjected to proton reactions, such as $\mathrm{HCO}_{3}$ and $\mathrm{H}_{2} \mathrm{CO}_{3}$. This dissolution of the ion grid results to neutralization of the $\mathrm{pH}$ solution. Moreover, as the system of the tested waters is open to free air, it is affected by atmospheric $\mathrm{CO}_{2}$, and more particularly by the $\mathrm{CO}_{3}{ }^{2-}, \mathrm{HCO}^{3-}$, and $\mathrm{H}_{3} \mathrm{O}^{+}$derivatives, which are able to accelerate the neutralization processes. During the experimental process, with the rise of $\mathrm{pH}, \mathrm{CO}_{2}$ passes in gas form, while at the same time during the neutralization process with magnesium, precipitation of small amounts of mud characterized by increased density and by containing metal hydroxides. Similar reports concerning magnesite $\left(\mathrm{MgCO}_{3}\right)$ activity in acidic solutions have been mentioned by Teir et al. [18]. However, even magnesite has been mentioned to be used for remediation of drainage waste water itself, magnesite has not been combined with other mineral raw materials in these conditions up to now. Magnesite led to smoother change of $\mathrm{pH}$ values in contrast to serpentinite due to its chemical composition and to its textural features. Ohta et al. [57] has reported that rocks such as andesite are considered to be effective in waste treatment processes.

The Pliocene andesite (BE.82) had a positive effect on the normalization of $\mathrm{pH}$ values due to its chemical composition, but was less effective than serpentinite and magnesite. In this rock, the increasing trend of $\mathrm{pH}$ values may happen due to its intermediate composition, as well as to the percentage of $\mathrm{CaO}$ that was positively contributed by a series of calcium neutralization reactions to acidic water (Table 3). An additional factor which may significantly influence the rise of $\mathrm{pH}$ values is its high porosity texture (Table 2), as a result of its microscopic structure (Figure $5 \mathrm{c}, \mathrm{d}$ ).

In the studied continuous flow device, a non-smooth fluctuation and a slight fall in $\mathrm{pH}$ values after day 4 is presented, a fact which is associated with the incorporation of the third filter of the device, which contains peat and biochar, as peat has the tendency to flush off small-scale humic acids in its initial contact with the solution. The $\mathrm{pH}$ of the solution constitutes a significant factor for the adsorption of metals depending on its value changing metal and adsorbent properties. The change in the $\mathrm{pH}$ value of the solution in the experimental device deposit determines the surface load of the adsorbent. When $\mathrm{pH}$ values are below 4, minerals prefer to bind protons instead of metal cations resulting in enhancing the positive charge of the adsorbent and repelling the metal cations. As the $\mathrm{pH}$ increases, the active groups of the mineral are deprotonated, resulting in an increase in the absorbers' negative charge and the attraction of the metal cations [58,59]. However, at high $\mathrm{pH}$ values, precipitation of metal complexes takes place reducing the available concentration of metals in the solution and hence to their adsorption [60]. The precipitation boosts the total removal of metals, as well as the reduction in their percentageous removal due to adsorption. For minerals, the minimum adsorption is observed at $\mathrm{pH} \leq 3$ while the maximum adsorption at $\mathrm{pH}$ 5-8 [61].

\subsection{Removal of Heavy Metals Using the Proposed Experimental Continuous Flow Device}

The results of the water geochemical analysis during the 7-day operation of the device suggest that the referred combination yielded satisfactory results with respect to the remediation of the removal of certain heavy metals such as $\mathrm{Fe}, \mathrm{Cu}$, and $\mathrm{Zn}$. However, the use of the combination of these mineral raw materials didn't perform satisfactorily for the removal of other heavy metals such as $\mathrm{Cd}, \mathrm{Ni}$, etc.

Figure 11 illustrates the concentration of $\mathrm{Fe}$ in the water during the seven days of experiment. An increase in the concentration of Fe in the first day is observed and can be explained due to the initial leaching of Fe from the serpentinite and the andesite, which contain small percentages of Fe. This is also due to contamination from the metallic parts of the pumps, as highly acidic solutions like the initially treated water promote solubility in the aerobic condition due to the oxidation of $\mathrm{Fe}^{2+}$ to $\mathrm{Fe}^{3+}$ through an increased oxidation potential, and the temporarily increased concentration until the $\mathrm{pH}$ increases. 


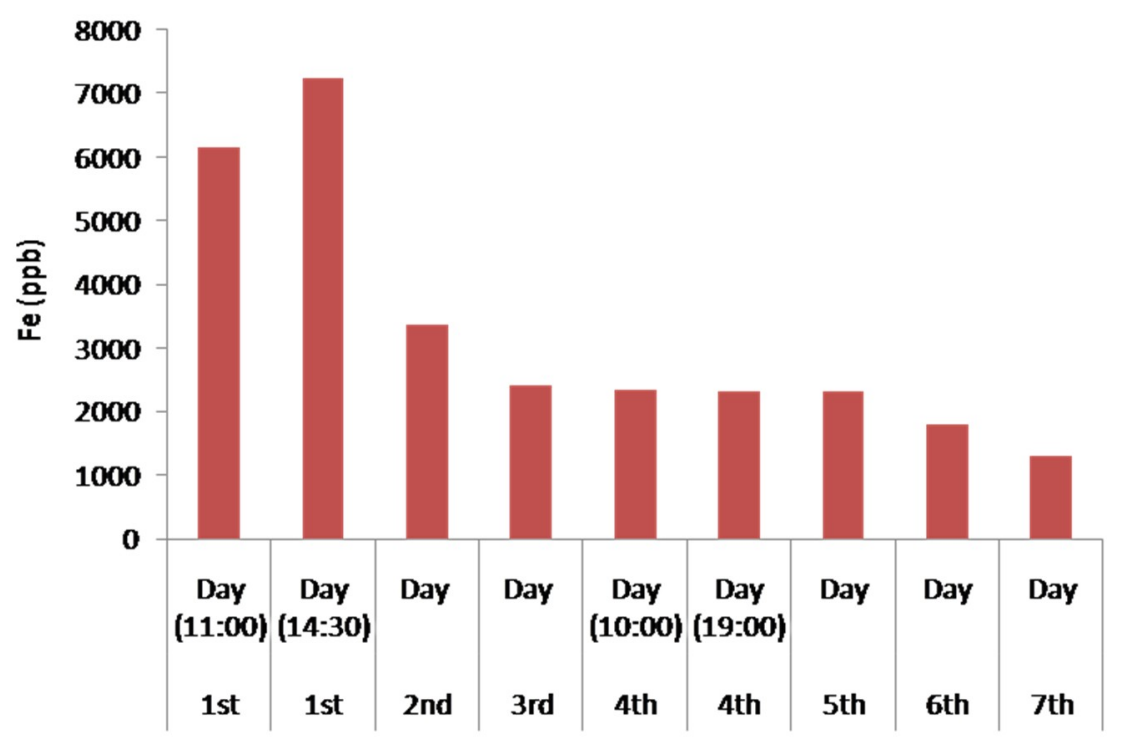

Figure 11. Histogram of Fe concentration in the treated water waste during the continuous water flow operation.

The reaction described above is feasible as follows:

$$
4 \mathrm{Fe}^{2+}+\mathrm{O}_{2}(\mathrm{aq})+4 \mathrm{H}^{+} \rightarrow 4 \mathrm{Fe}^{3+}+2 \mathrm{H}_{2} \mathrm{O}
$$

On the second day ( $\mathrm{pH}>4.5)$, there was a strong decrease in Fe concentration in the solution. During the neutralization reactions the presence of oxygen acting as an oxidizing agent and increased hydrolysis of the ferrous iron takes place with the precipitation of a series of compounds such as $\mathrm{Fe}(\mathrm{OH})_{3}$, as well as $\mathrm{FeOOH}$. The reaction describing the above process is:

$$
\mathrm{Fe}^{2+}+5 / 2 \mathrm{H}_{2} \mathrm{O}+1 / 4 \mathrm{O}_{2}(\mathrm{aq}) \rightarrow \mathrm{Fe}(\mathrm{OH})_{3}+2 \mathrm{H}^{+}
$$

Particularly important are considered to be the results of the experimental device concerning the removal of $\mathrm{Cu}$. In aqueous solutions, $\mathrm{Cu}$ occurs in two oxidation states, $\mathrm{Cu}^{+}$and $\mathrm{Cu}^{+2}[62]$. The solubility of $\mathrm{Cu}$ is very low under reducing conditions and is dissolved as $\mathrm{Cu}^{+}$. In contrast, under oxidizing conditions, solubility of $\mathrm{Cu}$ increases and the predominant species is $\mathrm{Cu}^{+2}[62,63]$. In general, it has been referred that the optimal removal of $\mathrm{Cu}$ is carried out in basic solutions as it strongly decreases the solubility and promotes the precipitation of the metal complex [60]. However, as shown in the histogram of Figure 12, the concentration of $\mathrm{Cu}$ decreased strongly in weakly acidic multi-constituent solutions, and more specifically by increasing from a $\mathrm{pH}$ value of 3 to values slightly above 4.5. This may happen due to the existence of strong complexes which where possible to be activated in these conditions depending on the contained minerals in filter boxes. Moreover, the $\mathrm{pH}$ value of the solution determines the adsorption of $\mathrm{Cu}$ in the laminated layers, especially the silicon tetrahedral by the ion exchange process. Additionally, $\mathrm{Cu}$ adsorption is feasible to be carried out on already precipitated Fe oxides (as mentioned above), which also depends on the large extent on $\mathrm{pH}$ and the available oxygen solution. This dependence on $\mathrm{Cu}$ is mainly due to the adsorption of its hydroxides, which form much stronger complexes than free $\mathrm{Cu}^{2+}$. The models of the surface of $\mathrm{Cu}$ adsorption occurring within the devices, in Fe oxides, Fe hydroxides, in clay minerals of andesites, as well as in serpentine of serpentinite based on adsorption of $\mathrm{Cu}^{2+}$ and to the simultaneous creation and adsorption $\mathrm{CuOH}^{+}$. 


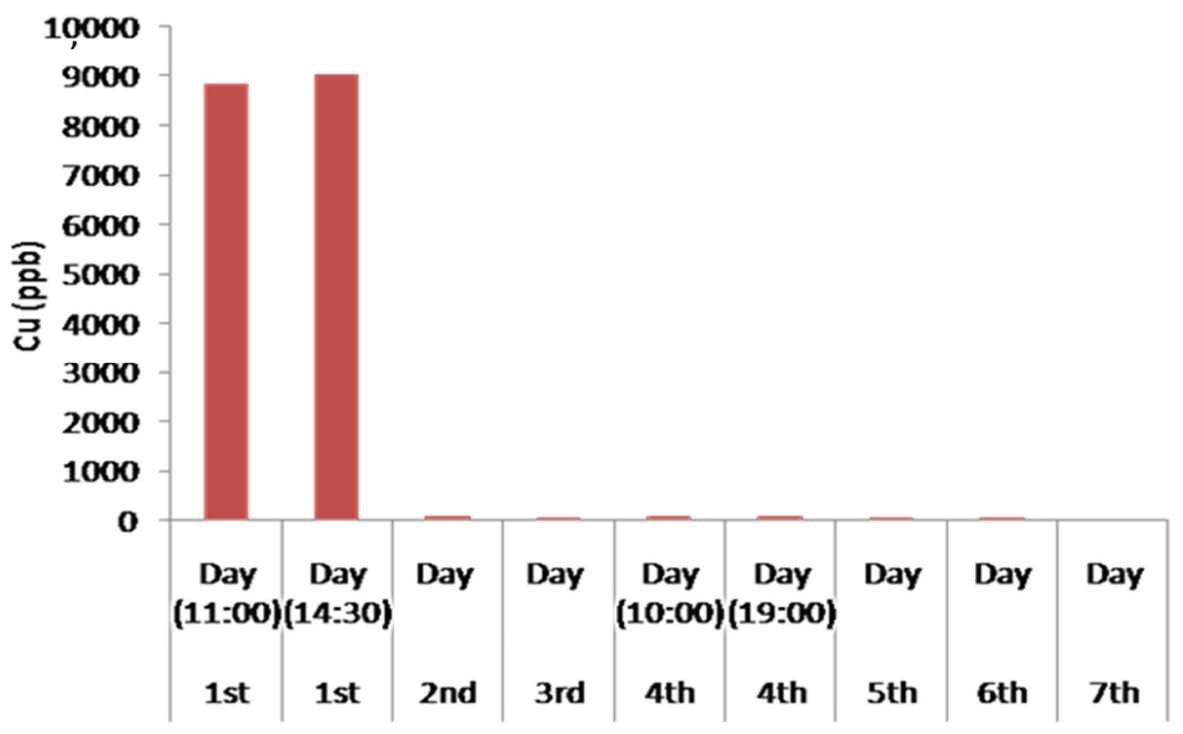

Figure 12. Histogram of the concentration of $\mathrm{Cu}$ in the treated water waste during the continuous water flow operation.

Recent studies have been carried out on the mechanical-chemical activation of serpentine in capturing and recovering $\mathrm{Cu}$ from polluted water. This new method presents substantial environmental and economic advantages both because the adsorption of $\mathrm{Cu}$ from the activated serpentine exhibiting very satisfactory results, and because serpentine allows the selective removal of $\mathrm{Cu}$ from polluted waters in which it coexists with other metals such as Ni, Mn, Zn, and Cd [53]. Mechanical activation is a method of exerting mechanical force to induce changes in surface properties and in crystal structure of minerals [64-68]. Although numerous studies have been carried out regarding the understanding of the nature of mechanical loadings in structural changes of mineral structure, the activation of such low-cost phylosilicate minerals has not yet been thoroughly studied in environmental applications of metal depletion.

In this study, the combined effect of abrasion and attrition on the surface of the serpentinite particles with the subsequent crushing to produce the desired particle size for the filters likely activated serpentine causing changes in its crystal structure. These structural changes typically happen after prolonged mechanical loading on serpentine, particularly affecting its hydroxyls, which can become smoother than in the octahedral positions and are easily released into the solution when coming into contact with it [53]. Since the structure of serpentine is destroyed by abrasive mechanical forces, it is unable to maintain the arrangement of its atoms and therefore alters its crystallinity. The change of the crystallinity of serpentine has been reported as one of the main causes of $\mathrm{Cu}$ adsorption [53]. The adsorption of $\mathrm{Cu}$ at $\mathrm{pH}$ values relatively low $(\mathrm{pH}=4.5)$ and contributes to the complexation and strong adsorption by serpentine minerals.

The designed device showed a remarkable capability in the removal of $\mathrm{Zn}$, as well. Zn showed behaviour similar to $\mathrm{Fe}$ as the first day its concentration in the treated water initially increased, but after the second day showed a constant and strong decrease. On the first day, a slight increase in $\mathrm{Zn}$ concentration had been observed. This increase may happen due to the presence of the brass angular mechanical connection of pipelines in the experimental device. The slightly increased $\mathrm{Zn}$ concentration in andesite may lead to the increase of the $\mathrm{Zn}$ concentration in the tested solution during the first operation day of the experimental device. Although $\mathrm{Zn}$ usually exhibits similar behaviour to $\mathrm{Cu}$ and $\mathrm{Pb}$, in this device, significantly different mobility behaviour has been observed. Also, change of a lower degree in $\mathrm{Zn}$ concentrations was observed for $\mathrm{pH}$ values below 5 . Similar conclusions have been cited by Gosset et al. [69] concerning satisfactory adsorption for $\mathrm{Zn}$ is at a $\mathrm{pH}$ higher than 5.5. The effect of $\mathrm{pH}$ on binding capacity is feasible in the tested device (and in particular in the third filter), as the 
lower the $\mathrm{pH}$, the higher the concentration of $\mathrm{H}^{+}$that compete for the adsorption of $\mathrm{Zn}^{2+}$ ions in peat cellulose is. The competitiveness of $\mathrm{Zn}^{2+}$ and $\mathrm{H}^{+}$ions at low $\mathrm{pH}$ values results in reduced adsorption of $\mathrm{Zn}$ ions to peat.

More specifically, at the end of the fourth operation day (at 19:00), increased $\mathrm{Zn}$ absorption of a stable rate from the fourth till the seventh operation day was observed (Figure 13). This is attributed to the entry of the third filter of the experimental device containing $50 \%$ peat and 50\% biochar (after 10:00) in combination with the simultaneously increase of $\mathrm{pH}$ values (>6.65). Several scientists have used filters of organic origin for the removal of heavy metals such as $\mathrm{Zn}$ [27].

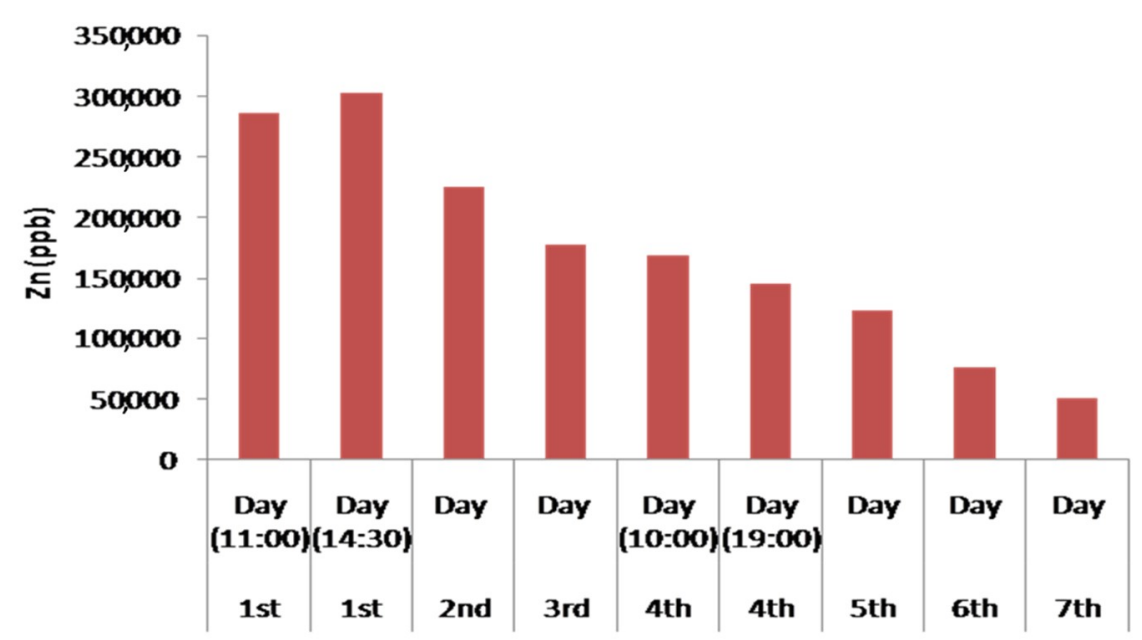

Figure 13. Histogram of the concentration of $\mathrm{Zn}$ in the treated water waste during the continuous water flow operation.

The adsorption mechanism of $\mathrm{Zn}$ ions and other metals in peat have been studied by many researchers without producing a single accepted neutralization model. Most theories approach bind by exploring different mechanisms such as the ion exchange, surface adsorption, chemical adsorption, complexing, and adsorption-complexing processes. The moss-derived peat constitutes a material used as complex having lignin and cellulose as main components. These compounds and more particularly lignin and humic acid, carry polar active groups, such as alcohols, aldehydes, ketones, carboxylic acids, phenolic hydroxides and ethers, which may be related to the formation of chemical bonds and complexes with the $\mathrm{Zn}$ ions [27]. Due to the polar character of the peat, the specific adsorption capacity for the dissolved elements such as for $\mathrm{Zn}$, and the partially removal from the tested solutions is strong. In addition, the $\mathrm{pH}$ reduction during the first hours of operation of the device by filtering through the third filter (peat-biochar) is in line with the principles of ion exchange since the more $\mathrm{Zn}$ ions and other metals are adsorbed on the peat, the more hydrogen ions are released, resulting in a decrease in $\mathrm{pH}$. Similar conclusions have been reported by Ho et al. [70], studying peat sorption by performing intermittent experiments, indicating that complexation and ion exchange presented as important factors for the sorption process. An additional reason for the increased ability of the device to significantly remove $\mathrm{Zn}$ is the existence of biochar within the third filter. In similar conclusions Chen et al. [71] has been conducted, as they identified high absorption capacity of biochar in metals such as Zn. Furthermore, Xu et al. [72] and Park et al. [73], reported the increased ability of biochar to bind metals such as $\mathrm{Zn}$ and $\mathrm{Cu}$. Both in peat and in biochar there is not yet a single mechanism for neutralizing $\mathrm{Zn}$ ions from the biochar structure. Most studies attribute the binding of metals such as $\mathrm{Zn}$ to complexation and ion exchange by electrostatic interaction. The pyrolysis of the initial peat as observed in Figures $7 \mathrm{c}$ and $8 \mathrm{e}$ produced a significantly porous heterogeneous material with particularly well-developed and distributed pores. Due to this structure, the reaction surfaces increase, and the carbon-rich mesh structure traps both physicochemically and mechanically complexed contaminants. 


\section{Conclusions}

The use of a combination of mineral raw materials has significantly improved the quality of waters when they were used in the new experimental electrical device for the remediation of Agios Phillippos Kirkis mine waste water drainage. The combination of mineral raw materials rich in $\mathrm{Mg}$ such as magnesite and serpentinite strongly reacted and remediated the $\mathrm{pH}$ of the drainage water waste. Furthermore, the increase of $\mathrm{pH}$ values due to the presence of mineral raw materials, as well as the increase of oxygen supply contributed to the deactivation of the toxic load of metals.

The exposure of $\mathrm{Fe}^{2+}$ in increased oxygen concentrations led through an increased oxidation potential to the formation of $\mathrm{Fe}^{3+}$ and the precipitation of a series of compounds such as $\mathrm{Fe}(\mathrm{OH})_{3}$. The concentration of $\mathrm{Cu}$ was strongly reduced by raising $\mathrm{pH}$ values from 3 to slightly above 4.5 , which is attributed to both the selective $\mathrm{Cu}$ adsorption of mechanically affected serpentine and the increase in $\mathrm{pH}$. The experimental device was particularly effective in $\mathrm{Zn}$ binding that was attributed to the use of an organic filter (peat and biochar) due to complexation and ion exchange by electrostatic interaction. However, this research even enriches the researches gaps relative to electrical continuous flow driven forced devices, it cannot constitute a unique way for the remediation of this type of phenomenon but it can act in synergy with other methods. Moreover, the present experimental device may serve as a useful tool for the use of different mixes of mineral raw materials in order to remediate drainage waste waters.

Author Contributions: P.P. participated in the fieldwork, the elaboration of laboratory tests, the interpretation of the results, coordinated the research and the writing of the manuscript; A.R. participated in the fieldwork, performed the SEM work, the interpretation of the results and contributed to the manuscript writing; P.P.G. participated in the fieldwork, the elaboration of laboratory tests, the interpretation of the results and contributed to the manuscript writing; B.T. participated in the interpretation of the results and contributed to the manuscript writing; P.L. carried out the XRD analyses, participated in the interpretation of the results and contributed to the manuscript writing; S.K. performed peat and biochar petrography and contributed to the manuscript writing; K.H. participated in the interpretation of the results; N.L. performed the water chemical analyses and participated in the interpretation of the results; and M.A.C. performed the laboratory tests.

Funding: This research received no external funding.

Acknowledgments: We kindly thank A.K. Seferlis of the Laboratory of Electron Microscopy and Microanalysis, University of Patras for his assistance. We also thank M. Kalpogiannaki for her assistance with the construction of the geological map, K. Perleros for his assistance in peat and biochar petrographic study and the anonymous reviewers who have improved the manuscript.

Conflicts of Interest: The authors declare no conflict of interest.

\section{References}

1. Weber, W.J.; McGinley, P.M.; Katz, L.E. Sorption phenomena in subsurface systems: Concepts, models and effects on contaminant fate and transport. Water Res. 1991, 25, 499-528. [CrossRef]

2. Salmon, S.U.; Oldham, C.; Ivey, G.N. Assessing internal and external controls on lake water quality: Limitations on organic carbon-driven alkalinity generation in acidic pit lakes. Water Resour. Res. 2008, 44, W10414. [CrossRef]

3. Schindler, D.W. The significance of in-lake production of alkalinity. Water Air Soil Pollut. 1986, 30, 931-944. [CrossRef]

4. Geller, W.; Klapper, H.; Salomons, W. Acidic Mining Lakes; Springer: Berlin/Heidelberg, Germany, 1998.

5. Geller, W.; Koschorreck, M.; Wendt-Potthoff, K.; Bozau, E.; Herzsprung, P.; Büttner, O.; Schultze, M. A pilot-scale field experiment for the microbial neutralization of a holomictic acidic pit lake. J. Geochem. Explor. 2009, 100, 153-159. [CrossRef]

6. Plumlee, G.S. The environmental geology of mineral deposits. In The Environmental Geochemistry of Mineral Deposits; Society of Economic Geologists (SEG): Littleton, CO, USA, 1999; pp. 71-116.

7. Lattanzi, P.; Da Pelo, S.; Musu, E.; Atzei, D.; Elsener, B.; Fantauzzi, M.; Rossi, A. Enargite oxidation: A review. Earth Sci. Rev. 2008, 86, 62-88. [CrossRef] 
8. Sperling, E.; Grandschamp, C.A.P. Possible water uses in mining lakes: Case study of Agua Claras, Brazil. In Access to Sanitation and Safe Water-Global Partnerships and Local Actions: Proceedings of the 33rd WEDC International Conference, Accra, Ghana, 7-11 April 2008; WEDC, Loughborough University: Loughborough, UK, 2008; pp. 375-380.

9. Shevenell, L.; Connors, K.A.; Henry, C.D. Controls on pit lake water quality at sixteen open-pit mines in Nevada. Appl. Geochem. 1999, 14, 669-687. [CrossRef]

10. Argun, M.E.; Dursun, S. A new approach to modification of natural adsorbent for heavy metal adsorption. Bioresour. Technol. 2008, 99, 2516-2527. [CrossRef]

11. Meena, A.K.; Kadirvelu, K.; Mishra, G.K.; Rajagopal, C.; Nagar, P.N. Adsorptive removal of heavy metals from aqueous solution by treated sawdust (Acacia arabica). J. Hazard. Mater. 2008, 150, 604-611. [CrossRef] [PubMed]

12. Panayotova, M.; Velikov, B. Influence of zeolite transformation in a homoionic form on the removal of some heavy metal ions from wastewater. J. Environ. Sci. Health. 2003, 38, 545-554. [CrossRef]

13. Amarasinghe, B.M.W.P.K.; Williams, R.A. Tea waste as a low cost adsorbent for the removal of $\mathrm{Cu}$ and $\mathrm{Pb}$ from wastewater. Chem. Eng. J. 2007, 132, 299-309. [CrossRef]

14. Barkat, M.A. New trends in removing heavy metals from industrial wastewater. Arab. J. Chem. 2011, 4, 361-377. [CrossRef]

15. Bai, Y.; Bartkiewicz, B. Removal of cadmium from wastewater using ion exchange resin Amberjet $1200 \mathrm{H}$ columns. Pol. J. Environ. Stud. 2009, 18, 1191-1195.

16. Hegazi, H.A. Removal of heavy metals from wastewater using agricultural and industrial wastes as adsorbents. Hbrc J. 2013, 9, 276-282. [CrossRef]

17. Lakherwal, D. Adsorption of heavy metals, a review. Int. J. Environ. Res. Dev. 2014, 4, 41-48.

18. Teir, S.; Eloneva, S.; Fogelholm, C.; Zevenhoven, R. Stability of calcium carbonate and magnesium carbonate in rainwater and nitric acid solutions. Energy Convers. Manag. 2006, 47, 3059-3068. [CrossRef]

19. Smith, M. Panasqueira the tungsten giant at 100+. Oper. Focus Int. Min. 2006, 33, 10-14.

20. Petrounias, P.; Giannakopoulou, P.P.; Rogkala, A.; Stamatis, P.M.; Tsikouras, B.; Papoulis, D.; Lampropoulou, P.; Hatzipanagiotou, K. The influence of alteration of aggregates on the quality of the concrete: A case study from serpentinites and andesites from central macedonia (North Greece). Geosciences 2018, 8, 115. [CrossRef]

21. Giannakopoulou, P.P.; Petrounias, P.; Rogkala, A.; Tsikouras, B.; Stamatis, P.M.; Pomonis, P.; Hatzipanagiotou, K. The influence of the mineralogical composition of ultramafic rocks on their engineering performance: A case study from the veria-naousa and gerania ophiolite complexes (Greece). Geosciences 2018, 8, 251. [CrossRef]

22. Petrounias, P.; Giannakopoulou, P.P.; Rogkala, A.; Lampropoulou, P.; Koutsopoulou, E.; Papoulis, D.; Tsikouras, B.; Hatzipanagiotou, K. The Impact of Secondary Phyllosilicate Minerals on the Engineering Properties of Various Igneous Aggregates from Greece. Minerals 2018, 8, 329. [CrossRef]

23. Petrounias, P.; Giannakopoulou, P.P.; Rogkala, A.; Stamatis, P.M.; Lampropoulou, P.; Tsikouras, B.; Hatzipanagiotou, K. The Effect of petrographic characteristics and physico-mechanical properties of aggregates on the quality of concrete. Minerals 2018, 8, 577. [CrossRef]

24. Giannakopoulou, P.P.; Petrounias, P.; Tsikouras, B.; Kalaitzidis, S.; Rogkala, A.; Hatzipanagiotou, K.; Tombros, S. Using factor analysis to determine the interrelationships between the engineering properties of aggregates from igneous rocks in Greece. Minerals 2018, 8, 580. [CrossRef]

25. Coupal, B.; Lalancette, J.M. The treatment of waste waters with peat moss. War. Res. 1976, 10, 1071-1076. [CrossRef]

26. McLellan, J.K.; Rock, C.A. Pretreating landfill leachate with peat to remove metals. Water Air Soil Pollut. 1988, 37, 203-215. [CrossRef]

27. Chaney, R.L.; Hundemann, P.T. Use of peat moss columns to remove cadmium from wastewaters. J. Water Pollut. Control Fed. 1979, 51, 17-21.

28. Sharma, D.C.; Forster, C.F. Removal of hexavalent chromium using sphagnum moss peat. Water Res. 1993, 27, 1201-1208. [CrossRef]

29. Gardea-Torresdey, J.L.; Tang, L.; Salvador, J.M. Copper adsorption by esterified and unesterified fractions of sphagnum peat moss and its different humic substances. J. Hazard. Mater. 1996, 48, 191-206. [CrossRef] 
30. Zhipei, Z.; Junlu, Y.; Zenghui, W.; Piya, C. A preliminary study of the removal of $\mathrm{Pb}\left({ }^{2+}\right), \mathrm{Cd}\left({ }^{2+}\right), \mathrm{Zn}\left({ }^{2+}\right)$, $\mathrm{Ni}\left({ }^{2+}\right)$, and $\mathrm{Cr}\left({ }^{2+}\right)$ from wastewaters with several Chinese peats. In Proceedings of the Seventh International Peat Congress, Dublin, Ireland, 18-23 June 1984; pp. 147-152.

31. Dennehy, C.; Lawlor, P.G.; Jiang, Y.; Gardiner, G.E.; Xie, S.; Nghiem, L.D.; Zhan, X. Green-house gas emissions from different pig manure management techniques: A critical analysis. Front. Environ. Sci. Eng. 2017, 11, 11. [CrossRef]

32. Feng, Z.; Zhu, L. Sorption of phenanthrene to biochar modified by base. Front. Environ. Sci. Eng. 2017, $12,1$. [CrossRef]

33. Li, Z.; Wang, F.; Bai, T.; Tao, J.; Guo, J.; Yang, M.; Wang, S.; Hu, S. Lead immobilization by geological fluorapatite and fungus Aspergillus niger. J. Hazard. Mater. 2016, 320, 386-392. [CrossRef]

34. Li, J.-S.; Beiyuan, J.; Tsang, D.C.; Wang, L.; Poon, C.S.; Li, X.-D.; Fendorf, S. Arsenic-containing soil from geogenic source in Hong Kong: Leaching characteristics and stabilization/solidification. Chemosphere 2017, 182, 31-39. [CrossRef]

35. Shen, Z.; Zhang, Y.; Jin, F.; McMillan, O.; Al-Tabbaa, A. Qualitative and quantitative characterisation of adsorption mechanisms of lead on four biochars. Sci. Total Environ. 2017, 609, 1401-1410. [CrossRef]

36. Lee, S.J.; Park, J.H.; Ahn, Y.T.; Chung, J.W. Comparison of heavy metal adsorption by peat moss and peat moss-derived biochar produced under different carbonization conditions. Water Soil Air Pollut. 2015, 226, 9. [CrossRef]

37. Skarpelis, N. The Agios Philippos ore deposit, Kirki (Western Thrace). A base metal part of a high sulfidation epithermal system. Bull. Geol. Soc. Gr. 1999, 33, 51-60.

38. Triantafyllidis, S. Environmental risk assessment of mining and processing activities and rehabilitation proposals in evros and rhodope prefectures (Thrace, NE Greece). Ph.D. Thesis, Faculty of Geology \& Geoenvironment, University of Athens, Athens, Greece, 2006.

39. Triantafyllidis, S.; Skarpelis, N. Mineral formation in an acid pit lake from a high-sulfidation ore deposit: Kirki, NE Greece. J. Geoch. Explor. 2006, 88, 68-71. [CrossRef]

40. Maratos, G.; Andronopoulos, V.; Koukouzas, K. Geological Map of Greece. Alexandroupolis Sheet. 1:50.000; IGME (Institute of Geology and Mineral Exploration): Athens, Greece, 1965.

41. Petrounias, P.; Rogkala, A.; Kalpogiannaki, M.; Tsikouras, B.; Hatzipanagiotou, K. Comparative study of physico-mechanical properties of ultrabasic rocks (Veria-Naousa ophiolite) and andesites from central Macedonia (Greece). Bull. Geol. Soc. Gr. 2016, 50, 1989-1998.

42. Rogkala, A.; Petrounias, P.; Tsikouras, B.; Hatzipanagiotou, K. Petrogenetic significance of spinel from serpentinised peridotites from Veria-Naousa ophiolite. Bull. Geol. Soc. Gr. 2016, 50, 1999-2008.

43. Rogkala, A.; Petrounias, P.; Tsikouras, B.; Hatzipanagiotou, K. New occurrence of pyroxenites in the Veria-Naousa ophiolite (north Greece): Implications on their origin and petrogenetic evolution. Geosciences 2017, 7, 92. [CrossRef]

44. Rogkala, A.; Petrounias, P.; Tsikouras, B.; Giannakopoulou, P.P.; Hatzipanagiotou, K. Mineralogical Evidence for Partial Melting and Melt-Rock Interaction Processes in the Mantle Peridotites of Edessa Ophiolite (North Greece). Minerals 2019, 9, 120. [CrossRef]

45. Lester, E.; Alvarez, D.; Borrego, A.G.; Valentim, B.; Flores, D.; Clift, D.A.; Rosenberg, P.; Kwiecińska, B.; Barranco, R.; Petersen, H.I.; et al. The procedure used to develop a coal char classification-Commission III combustion working group of the international committee for coal and organic petrology. Int. J. Coal Geol. 2010, 81, 333-342. [CrossRef]

46. Sýkorová, I.; Pickel, W.; Christanis, K.; Wolf, M.; Taylor, G.H.; Flores, D. Classification of huminite-ICCP System 1994. Int. J. Coal Geol. 2005, 62, 85-106. [CrossRef]

47. Pickel, W.; Kus, J.; Flores, D.; Kalaitzidis, S.; Christanis, K.; Cardott, B.J.; Misz-Kennan, M.; Rodrigues, S.; Hentschel, A.; Hamor-Vido, M.; et al. Classification of liptinite-ICCP System 1994. Int. J. Coal Geol. 2017, 169, 40-61. [CrossRef]

48. Bish, D.L.; Post, J.E. Quantitative mineralogical analysis using the Rietveld full pattern fitting method. Am. Mineral. 1993, 78, 932-940.

49. Brown, E. ISRM Suggested Methods. Rock Characterization Testing and Monitoring; London Royal School of Mines: London, UK, 1981.

50. Maschio, G.; Koufopanos, C.; Lucchesi, A. Pyrolysis, a Promising Route for Biomass Utilization. Biores. Technol. 1992, 42, 219-231. [CrossRef] 
51. González, J.F.; Román, S.; Encinar, J.M.; Martínez, G. Pyrolysis of various biomass residues and char utilization for the production of activated carbons. J. Anal. Appl. Pyrolysis 2009, 85, 134-141. [CrossRef]

52. Hawke, M.I.; Martini, I.P.; Stasiuk, L.D. A comparison of temperate and boreal peats from Ontario, Canada: Possible modern analogues for Permian coals. Int. J. Coal Geol. 1999, 41, 213-238. [CrossRef]

53. Pengwu, H.; Zhao, L.; Min, C.; Huimin, H.; Zhiwu, L.; Qiwu, Z.; Wenyi, Y. Mechanochemical activation of serpentine for recovering CU (II) from waste water. Appl. Clay Sci. 2017, 149, 1-7.

54. Kleiv, R.A.; Thornhill, M. Adsortive retention of copper from acidic mine water at the disused sulphide mine at Løkken, central Norway-initial experiments using olivine. Miner. Eng. 2004, 17, 195-203. [CrossRef]

55. Handols, T. Det nya Sattet att Hejda Forsurningen; 1983.

56. Crundwell, F.K. The mechanism of dissolution of minerals in acidic and alkaline solutions: Part I-A new theory of non-oxidation dissolution. Hydrometallurgy 2014, 149, 252-264. [CrossRef]

57. Ohta, K.; Ahsan, S.; Kaneco, S.; Suzuki, T.; Mizuno, T.; Kani, K. Treatment of waste water with rocks (andesite, granite, marble), refuse concrete and refuse cement. In Proceedings of the Fourth Asian Symposium on Academic Activity for Waste Management and Resources; pp. 162-168.

58. Acheampong, M.A.; Meulepas, R.J.W.; Lens, P.N.L. Removal of heavy metals and cyanide from gold mine wastewater. J. Chem. Technol. Biotechnol. 2010, 85, 590-613. [CrossRef]

59. Farooq, U.; Kozinski, J.A.; Khan, M.A.; Athar, M. Biosorption of heavy metal ions using wheat based biosorbents-A review of the recent literature. Bioresour. Technol. 2010, 101, 5043-5053. [CrossRef] [PubMed]

60. Vijayaraghavan, K.; Yun, Y.-S. Bacterial biosorbents and biosorption. Biotechnol. Adv. 2008, 26, $266-291$. [CrossRef]

61. Sen, T.K.; Gomez, D. Adsorption of zinc $\left(\mathrm{Zn}^{2+}\right)$ from aqueous solution on natural bentonite. Desalination 2011, 267, 286-294. [CrossRef]

62. Thornbern, M.R. Supergene alteration of sulphides. VII. Distribution of elements during the gossan-forming process. Chem. Geol. 1985, 53, 279-301.

63. Nolan, A.L.; McLaughlin, M.J.; Mason, S.D. Chemical speciation of Zn, Cd, Cu and Pb in pore waters of agricultural and contaminated soils using Donnan analysis. Environ. Sci. Technol. 2003, 37, 90-98. [CrossRef]

64. Chen, M.; Li, Z.; Li, X.W.; Qu, J.; Zhang, Q.W. Mechanochemically extracting tungsten through caustic processing of scheelite by controlling calcium dissolution. Int. J. Refract. Met. Hard. Mater. 2016, 58, 211-215. [CrossRef]

65. James, S.L.; Adams, C.J.; Bolm, C.; Braga, D.; Collier, P.; Friscic, T.; Grepioni, F.; Harris, K.D.; Hyett, G.; Jones, W.; et al. Mechanochemistry: Opportunities for new and cleaner synthesis. Chem. Soc. Rev. 2012, 41, 413-447. [CrossRef]

66. Li, J.; Hitch, M. Mechanical activation of ultramafic mine waste rock in dry condition for enhanced mineral carbonation. Miner. Eng. 2016, 95, 1-4. [CrossRef]

67. Li, Z.; Chen, M.; Zhang, Q.W.; Liu, X.Z.; Saito, F. Mechanochemical processing of molybdenum and vanadium sulfides for metal recovery from spent catalysts wastes. Waste Manag. 2016, 60, 734-738. [CrossRef]

68. Vdović, N.; Jurina, I.; Škapin, S.D.; Sondi, I. The surface properties of clay minerals modified by intensive dry milling-Revisited. Appl. Clay Sci. 2010, 48, 575-580. [CrossRef]

69. Gossett, T.; Trancart, J.-L.; Thevenot, D.R. Batch metal removal by peat kinetics and thermodynamics. Water Res. 1986, 20, 21-26. [CrossRef]

70. Ho, Y.S.; Wase, D.A.J.; Forster, C.F. Batch nickel removal from aqueous solution by Sphagnum moss peat. Water Res. 1995, 29, 1327-1332. [CrossRef]

71. Chen, X.; Chen, G.; Chen, L.; Chen, Y.; Lehmann, J.; McBride, M.B.; Hay, A.G. Adsorption of copper and zinc by biochars produced from pyrolysis of hardwood and corn straw in aqueous solution. Bioresour. Technol. 2011, 102, 8877-8884. [CrossRef] [PubMed]

72. Xu, X.; Cao, X.; Zhao, L.; Wang, H. Removal of $\mathrm{Cu}, \mathrm{Zn}$, and $\mathrm{Cd}$ from aqueous solutions by the dairy manure-derived biochar. Environ. Sci. Pollut. Res. 2013, 20, 358-368. [CrossRef] [PubMed]

73. Park, J.H.; Wang, J.J.; Kim, S.H.; Cho, J.S.; Kang, S.W.; Delaune, R.D.; Han, K.J.; Seo, D.C. Recycling of rice straw through pyrolysis and its adsorption behaviors for $\mathrm{Cu}$ and $\mathrm{Zn}$ ions in aqueous solution. Colloids Surf. 2017, 533, 330-337. [CrossRef]

(C) 2019 by the authors. Licensee MDPI, Basel, Switzerland. This article is an open access article distributed under the terms and conditions of the Creative Commons Attribution (CC BY) license (http://creativecommons.org/licenses/by/4.0/). 